\title{
0 Conselho de Jurados do Termo da Vila de São José del-Rei, um estudo de caso (1832-1841)
}

The Jurors's Council the Term of São

José del-Reis' Town, a Case Study

(1832-1841)

\author{
Viviane Penha Carvalho Silva \\ Ameno \\ Graduada em História pela \\ Universidade Federal de São João \\ del-Rei (UFSJ - São João del-Rei/ \\ Brasil) e Mestre em História pela \\ Universidade Federal de Minas Gerais \\ (UFMG - Belo Horizonte/Brasil) \\ e-mail:vivianepcs@yahoo.com.br
}

\section{Resumo}

Neste artigo, apresento um estudo de caso: o modo como o corpo de jurados se constituiu socioeconomicamente e atuou numa comunidade particular, o Termo da Vila de São José del-Rei. Através dos crimes praticados no termo, busquei investigar a atuação de seu conselho de jurados durante a primeira década de funcionamento da instituição no Brasil (1832-1841). Com essa investigação, procurei perceber se tal conselho frustrou ou atendeu as expectativas atribuídas ao júri para melhoria da justiça que, na época, se praticava. Também tentei perceber como era a operacionalização dessa justiça, abordando temas que pudessem trazer luz ao modo como os tribunais, na prática, funcionavam e, assim, indicar a estrutura encontrada pelo jurado quando estava em serviço.

\section{Abstract \\ In this article I work a case study: how the jury was socioeconomically formed and how it acted in a particular community - the term of São José del-Rei's town. From the crimes comitted in this region I tried to analyse the actions of its council of jurors during the first decade of operation of this institution in Brazil (1832-1841). From this research I tried to find whether such council frustrated or met the jury expectations in order to improve the way justice operated at that time. I also tried to find out how justice operated, adressing issues that could clarify how the courts worked and thus show the structure found by the juror while working.}

Palavras-chave

Júri, São José del-Rei, processo criminal, elite, cidadania

Keywords

Jury, São José del-Rei, process criminal, elite, citizenship 
NEQUETE, Lenine. O poder judiciário no Brasil após a Independência. Porto Alegre: Sulina, 1972. p.25.

De modo geral o modelo judicial de Antigo Regime assinalava-se pela pluralidade jurídica (coexistência de complexos de normas distintos, atuando no mesmo espaço social e com igual autenticidade), pelo caráter doutrinal (o direito não era objetivo, o que conferia aos julgadores enorme autonomia na decisão das causas), pela não generalidade legal (as situações legais eram avaliadas nos seus termos particulares e dissociadas do todo, orientação que estava baseada na composição corporativa daquela sociedade). No direito criminal o processo era de cunho inquisitório, não havia proporcionalidade entre delito e pena, sua tônica era a exemplaridade. Sobre o assunto ver: HESPANHA, Antonio Manuel. Justiça e Litigiosidades: História e Prospectiva. Lisboa: Edição da Fundação Calouste Gulbenkian, 1993 e Cultura Jurídica Européia: Sintese de um Milênio. Florianópolis: Fundação Boiteux, 2005; LARA, Silvia Hunold. Ordenações Filipinas: Livro V. São Paulo: Companhia das Letras, 1999; FOUCAULT, Michel. Vigiar e punir: Nascimento da Prisão. Petrópolis: Vozes, 1987; SUBTIL, José Manuel Lopes. Sistema Penal e Construção do Estado Liberal: algumas questões em torno da Revolução de 1820. Faculdade de ciências Sociais e Humanas da Universidade de Nova Lisboa, março de 1987; BARREIROS, José Antônio. As Instituições Criminais em Portugal no Século XIX: Subsídios para a sua história. Análise Social: revista do Instituto de Ciências Sociais da Universidade de Lisboa, Lisboa, Vol. XVI, n.63, 1980

3

Anaes do Parlamento Brasileiro, Assembleia Legislativa, sessão de 10 de maio de 1830, fala do deputado Paula e Souza, p.98. Disponivel em: <www2.camara.gov.br>. Acesso em: 16/03/2012.

4

Ibidem, Assembleia Constituinte, sessão de 24 de outubro de 1823, fala do deputado Alencar, p. 140. Disponivel em: <www2.camara.gov.br>. Acesso em: 16/03/2012
Júri no Brasil: criação e expectativas

0 júri surge no mundo luso-brasileiro vinculado à abertura da liberdade de imprensa. Pelo decreto de 2 de março de 1821, ficava suspensa a prévia censura exigida na legislação que à época vigorava. Quatro meses mais tarde, seria decretado que o juízo competente para conhecer os delitos cometidos por abuso da liberdade de imprensa pertenceria aos conselhos de juízo de fato. Em Portugal, os conselhos se formariam a partir da eleição, nos distritos, de cidadãos de conhecida probidade, inteligência e boa fama. No Brasil, o júri seria criado um ano depois, como uma indicação das Cortes reunidas em Lisboa, por ocasião da Revolução do Porto. 0 decreto de 18 de junho de 1822 criava um tribunal de juízes de fato, composto de 24 cidadãos - homens bons, honrados, inteligentes e patriotas - nomeados pelo Corregedor do Crime da Corte e Casa, pelo Ouvidor do Crime nas províncias que tivessem Relação, ou, nas demais, pelo Juiz da Comarca. ${ }^{1} 0$ surgimento do júri, ainda que restrito ao julgamento de crimes de imprensa, enuncia a confirmação de transformações que já havia algum tempo se operavam no direito e na justiça portuguesa. 0 júri é uma instituição própria desses novos tempos, repercutindo em si vários aspectos inerentes ao liberalismo e, concomitantemente, rechaçando outros aspectos conformadores do modelo judicial de Antigo Regime. ${ }^{2}$

No Brasil independente o sistema de jurados foi pensado e estruturado dentro do contexto de descolonização e da formação do Estado Nacional, quando esse novo país reclamava novas instituições. Em uma de suas reflexões, o deputado brasileiro Paula e Souza disse que, em qualquer regime, o mais difícil era organizar o sistema judiciário (e o financeiro). Tarefa, para ele, ainda mais trabalhosa por se dar na passagem de um sistema colonial e despótico para um sistema representativo. Refletiu, por isso, que um sistema completo judiciário não seria obra de um dia, e talvez não fosse obra de muitos anos. ${ }^{3} \mathrm{~A}$ implementação do júri com competência ampliada ao julgamento de causas que não se restringissem ao abuso da liberdade de imprensa seria aprovada após um trabalho árduo de debates nas Assembleias Legislativas. As discussões iniciadas em 1823 se prolongaram por quase uma década. Quando, em 1832, por meio do Código do Processo Criminal, foram estabelecidas a forma e competência do júri como instância jurídica criminal, uma grande expectativa cumulava-se em relação à instituição. Sobre o júri, foram depositadas numerosas esperanças de melhora da justiça.

Quanto aos melhoramentos da justiça, o júri prometia ser a garantia dos direitos individuais, uma vez que protegeria a liberdade do cidadão e a segurança de sua propriedade, dois direitos caríssimos à perspectiva liberal, à qual esteve alinhada a Constituição de 1824. Assim sendo, o julgamento por jurados, nas causas criminais, resguardava ao acusado um juizo que, supostamente, não atentaria contra sua liberdade, visto que a apreciação de sua falta seria avaliada por seus iguais, os juízes leigos. Esse privilégio nas causas civis garantiria a defesa dos bens do acusado, principalmente diante do Estado. A respeito dessas garantias, na Constituinte de 1823, o deputado Alencar, intitulando-se "advogado da causa da liberdade brasileira", afirmava a "santíssima instituição dos jurados como primeira garantia da segurança individual do cidadão"4. Da mesma forma, confirmava a utilidade da instituição para o asseguramento da propriedade dos indivíduos. Era preciso "melhorar a sorte dos povos", pois a estabilidade das instituições não se garantiria sem a 
Ibidem, p.143. Disponivel em:

<www2.camara.gov.br>. Acesso em: 16/03/2012.

6

Ibidem, p.142. Disponivel em:

<www2.camara.gov.br>. Acesso em: 16/03/2012.

7

Ibidem, p.141. Disponivel em:

<www2.camara.gov.br>. Acesso em: 16/03/2012. segurança da propriedade dos cidadãos. Seu tom era de defesa do júri, mas também de alerta a assembleia: "na administração de justiça é que existem mais abusos, e é nela que devemos fazer a maior reforma; se não praticarmos assim, os povos farão novas revoluções vendo que não são remediados naquilo em que eles mais sofrem"5. A implementação do sistema de jurados era vista, então, como uma questão que poderia exercer influência na harmonia social.

Ainda sobre os benefícios da instituição, conjeturava-se que o juízo dos jurados implicaria agilidade à justiça, garantindo aos litigantes uma resolução mais rápida de suas demandas. 0 mesmo deputado, Alencar, aventou essa expectativa. Em sua concepção, ainda que o júri cometesse injustiças nas decisões dos pleitos, elas não prejudicariam mais os indivíduos do que a demora da justiça que à época se praticava. "Imensas fadigas, prejuízos e incômodos" eram gerados por aquela justiça que só alcançava satisfação em "20 e 30 anos" de causa. Por esse motivo, de acordo com 0 deputado, com o júri "a sociedade ganha o tempo precioso que os indivíduos perdem em semelhantes pleitos, podendo empregá-lo em coisas úteis; e o mesmo indivíduo que sofresse injustiça ao menos Ihe ficaria o tempo livre para em outras ocupações recuperar o prejuízo"6. Por conseguinte, as grandes delongas dos litígios faziam a justiça tardia pior que a injustiça. Além disso, os jurados, por dividirem a feitura da justiça com os magistrados, afirmavam a máxima do sistema constitucional pactuado pela sociedade brasileira: dividir, quanto possivel, o sistema de governo. "Não só a soberania da nação está dividida nos três poderes soberanos, legislativo, executivo e judiciário, mas que cada um destes poderes já assim divididos, não esta a cargo de um só indivíduo"7. Logo, o sistema de jurados era conforme o regime constitucional abraçado pela nação e seus representantes.

$\mathrm{Na}$ verdade, nesse período de discussões, o juízo por jurados era uma promessa de melhora do sistema jurídico. A execução de uma reforma na justiça e do direito herdado de Portugal era uma realidade, não havendo contestações a esse respeito. Era preciso responder as expectativas dos povos e garantir seus direitos em uma codificação que fosse objetiva. Não estava certo, porém, que tal reforma incorporaria a ampliação da competência do juízo por jurados decidindo as causas civis e criminais. Que a natureza do juízo por jurados era em si mesma repleta de benefícios que poderiam contribuir com a melhoria da feitura da justiça, poucos duvidavam. No entanto, era certo que, os povos demorariam a desfrutar de tão grande proveito: a mesma constituição que garantiu esse direito atravancou sua efetivação, uma vez que atrelou sua regulamentação à elaboração de códigos. Na Carta Constitucional de 1824, ficou prevista, no artigo 151, a independência do poder judicial. Tal poder, conforme o mesmo artigo, seria composto por juizes e jurados os quais teriam lugar no civil e no crime nos casos e pelo modo que os códigos determinassem. A ampliação da competência do júri estava, então, condicionada a determinações de códigos que sequer existiam. Assim, os jurados só deliberariam nos tribunais brasileiros sobre matérias criminais a partir da promulgação dos códigos que regularizassem tais matérias: o Código Criminal em 1830 e o Código do Processo Criminal em 1832. As causas civis nunca seriam julgadas pelo júri. A elaboração do Código Civil ultrapassaria a existência do próprio Império sendo promulgado somente em $1916 .{ }^{8}$

A vista disso, a investigação referente ao trabalho dos jurados se restringe ao exame de suas atuações nas causas criminais. Este artigo 
9

Entre as assinaturas, não foram encontrados nas listas nominativas 73 jurados. Há homonimia entre 22 nomes apurados; esses não foram utilizados devido à dificuldade em precisar quem entre esses seria o jurado identificado. 0 número de jurados encontrados nas listas soma o número de 170.

10

PAIVA, Clotilde de Andrade. População e Economia nas Minas Gerais do Século XIX. 1996. 229 f. Tese (Doutorado em História). Faculdade de Filosofia, Letras e Ciências Humanas, USP, São Paulo, 1996, p.47. destina-se a verificar, a partir do estudo de caso do conselho de jurados do Termo da Vila de São José del-Rei, em que medida tal conselho pôde atender as expectativas conferidas à instituição no melhoramento da justiça praticada naqueles tempos.

Os processos criminais do Fórum de Oliveira compuseram o material básico de pesquisa para cumprimento do propósito de entender 0 modo como atuaram os jurados do Termo da Vila de São José. Essa documentação está, hoje, sob guarda da Universidade Federal de São João del-Rei, que promoveu, em seu Laboratório de Conservação e Pesquisa Documental (LABDOC), a identificação, a restauração, a catalogação e a digitalização desses documentos que, há alguns anos, sofreram muitas danificações, após uma enchente invadir o prédio onde estavam alocados em Oliveira. Foram analisados todos os processos que possuiam data de julgamento em sessão do júri compreendida entre os anos de 1832 e 1841. 0 recorte se fixa entre o início do funcionamento do júri até 0 último ano de seu exercício, tal qual foi estabelecido pelo Código do Processo Criminal Brasileiro antes de sua primeira reforma, em 1842. 0 montante dessa documentação perfaz o total de 41 processos analisados. Neles foram levantados 265 nomes de jurados a partir de suas assinaturas constantes nos autos das sessões pesquisadas. ${ }^{9}$ Com relação aos trabalhos do júri, a maioria dos processos só apresenta a assinatura dos jurados e as sentenças do conselho. Poucos documentos trazem a ata de abertura da sessão de julgamento (onde se descrevia os procedimentos e ritos jurídicos a que se submetiam os participantes da sessão). Quanto ao mais, a documentação é rica em detalhes do modo de vida, crença e valores dos personagens envolvidos nos processos, quer se figurem como testemunhas, acusados ou ofendidos - ainda que seus relatos estejam, ali, traduzidos pela redação do escrivão.

A busca por informações referentes aos jurados foi efetuada em outro corpus documental, as listas nominativas. Clotilde Paiva referiuse às listas como um "conjunto de dados demográficos com alcance de censo provincial"10. Em seu conteúdo encontram-se informações relativas ao nome, estado civil, idade, cor, ocupação, local de moradia e escravaria dos chefes de fogo e seus dependentes. Em minha pesquisa utilizei-me das listas de 1831 e 1838 por coincidirem com o período pretendido para levantamento dos jurados. Cada nome assinado nos processos foi procurado nesses alistamentos. 0 cruzamento desses nomes com as informações disponiveis nas listas nominativas teve o intuito de traçar 0 perfil socioeconômico do conselho do Termo de São José para responder a algumas questões referentes ao funcionamento da instituição. Dentre elas: o júri representava-se por sujeitos independentes e, por isso, menos vulneráveis aos subornos e as pressões dos potentados locais? 0 conselho constituiu-se de indivíduos intelectualmente capacitados para julgar as ações postas à sua apreciação? Existia uma heterogeneidade socioeconômica, no júri, que garantisse a todos os acusados um julgamento isento, estabelecendo assim o princípio da igualdade de todos perante a lei? Todas essas perguntas se voltam à outra mais abrangente: o novo país, suas novas instituições, seu modelo constitucional e representativo ampliou efetivamente a participação da sociedade nos espaços abertos pela nova prática política liberal? 
11

VELLASCO, Ivan de Andrade. 0 controle da violência criminal em uma comarca de Minas Gerais - século XIX. Estudos Ibero-Americanos. PUCRS, v.XXIX, n.2. p.88, dezembro 2003.

12

Ibidem, p.89.

13

MALAQUIAS, Carlos de Oliveira. Trabalho, Família e Escravidão: pequenos produtores de São José do Rio das Mortes, de fins do século XVIII a meados do XIX. 2010. 153f. Dissertação (Mestrado em História). Faculdade de Filosofia a Ciências Humanas, Universidade Federal de Minas Gerais, Belo Horizonte, 2010. p.30.
14

Segundo Mário Rodarte "entre as condições sociais, livre e escravo eram as mais freqüentes. Forros e quartados eram menos incidentes, inclusive pela menor frequência dessas condições, mas também por não constituir em categorias exigidas no ofício que solicitava 0 levantamento das listas. Por isso, forros poderiam ser classificados, simplesmente, como livres e quartados, como escravos. A ausência dessa informação, em geral, foi tomada como indicação do indivíduo ser livre, pelo elevado número de casos de não informação de condição entre os brancos". RODARTE, Mario Marcos Sampaio. 0 Trabalho do Fogo: perfis de domicilios enquanto unidades de produção e reprodução na Minas Gerais Oitocentista. 2008. 365f. Tese (doutorado em Demografia). Faculdade de Ciências Econômicas, Universidade Federal de Minas Gerais, Belo Horizonte, 2008. p.81.
O Termo da Vila de São José del-Rei: sociedade e economia

0 Termo de São José situava-se na Comarca do Rio das Mortes "uma das três primeiras existentes na capitania das Minas Gerais, sendo instituída em 1714"11. No último quartel do século XVIII a comarca já era responsável pelo abastecimento de gêneros da capitania. Esta precoce especialização agrícola iria transformá-la no celeiro estratégico fornecedor de produtos ao mercado litorâneo. No início do XIX, não era a maior geograficamente, mas era a mais populosa da Província de Minas. ${ }^{12}$ A região do Termo de São José se assentava ali em ocupação antiga, originada pelo ímpeto minerador, mas sustentada pela expansão de novas áreas devido à produção mercantil de alimentos: o desenvolvimento da região direcionou-se para o oeste com a incorporação de terras férteis. ${ }^{13} 0$ termo, em 1831, era dividido em 21 distritos, a saber: Lagoa Dourada, Santa Rita do Rio Abaixo, Passatempo, Santana do Jacaré, Ressaca, Olhos D'Água, Cláudio, Carmo da Mata, Cana Verde, Lage, Prados, Perdões, Carmo do Japão, Vila de São José, Desterro, Bom Sucesso, Santo Antônio do Amparo, Padre Gaspar, Oliveira, São Tiago e São João Batista.

Mapa 1: Termo da vila e extensão da freguesia de São José do Rio das Mortes na década de 1820.

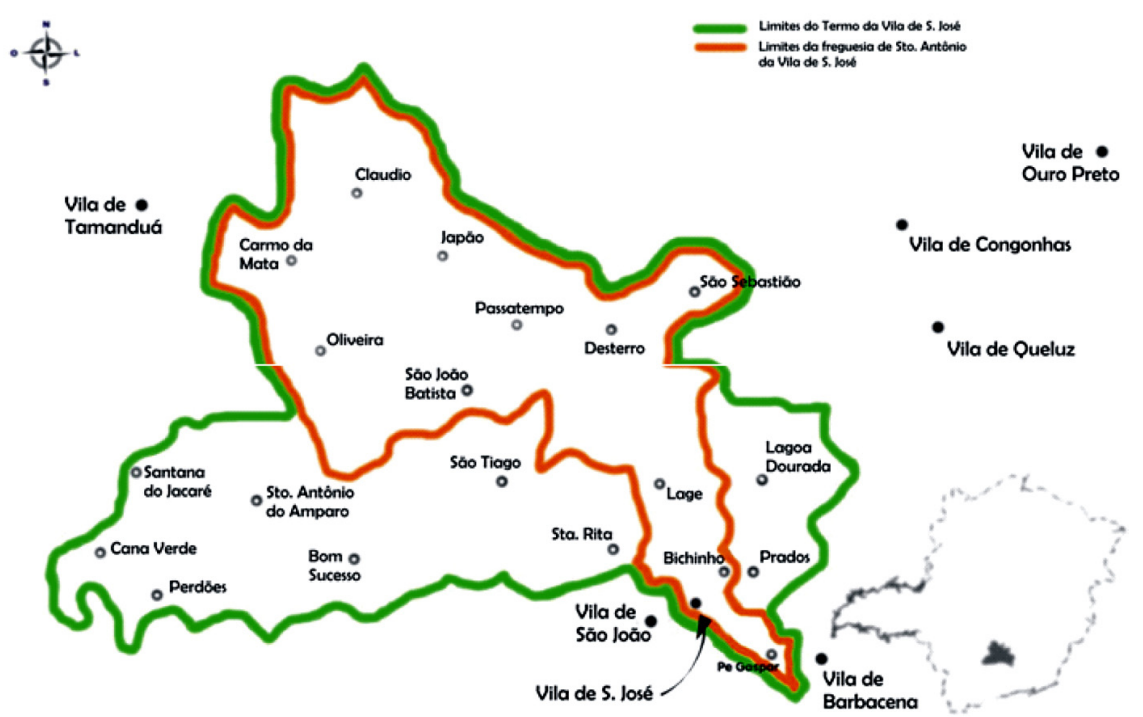

Fonte: MALAQUIAS, Carlos de Oliveira. Trabalho, Família e Escravidão: pequenos produtores de São José do Rio das Mortes, de fins do século XVIII a meados do XIX. Dissertação (Mestrado em História). Faculdade de Filosofia a Ciências Humanas, Universidade Federal de Minas Gerais, Belo Horizonte, 2010. p.18.

0 Termo de São José tinha por cabeça a vila de São José, que distava, de São João del-Rei - cabeça da Comarca - somente duas léguas. Segundo a listagem de 1831, havia no termo uma população de 33.067 habitantes predominantemente não brancos: 70,5\% de pretos, crioulos, pardos, cabras e africanos. A maior parte dessa população, 59,1\% dos indivíduos, era livre. ${ }^{14}$ É bastante significativo, entretanto, que os cativos somassem 13.497 indivíduos e representassem pouco mais de $40 \%$ da população do termo. Verificar a composição da população tendo-se em vista o aspecto da condição social é importante, pois dele se infere o grau de desenvolvimento da região. " 0 escravo é a riqueza na sociedade da época e sua presença mais ou menos expressiva pode (...) ajudar a distinguir as regiões segundo seu dinamismo"15. 0 Termo de São José se inseria, conforme classificação de 
17

Acrescentei à sua divisão a categoria posse média grande: 11 a 30 escravos. Meu objetivo foi separar de maneira mais minuciosa o grupo de jurados proprietários. LIBBY, Douglas Cole. Transformação e trabalho em uma economia escravista: Minas Gerais no século XIX. São Paulo: Brasiliense, 1988. p.104

18

PAIVA, Clotilde de Andrade. Op. Cit., p.137.
Clotilde Paiva, em uma das regiões mais desenvolvidas de Minas, a região Intermediária de Pitangui-Tamanduá. ${ }^{16}$

A estratificação social do regime escravista além de separar livres e escravos, também se fixava pela distinção entre proprietários e não proprietários. Ao tomar o escravo como "medida de riqueza" alguns dados importantes em relação ao termo são verificados através dos números de domicílios possuidores de escravos e a difusão das posses sanjoseenses. Mediante as tabelas 1 e 2 pode-se notar que o Termo de São José não se diferenciava do perfil escravista de Minas Gerais, onde predominava a existência de fogos sem escravos: 0 percentual de 39.2\% de proprietários não está fora da média provincial. Logo, no termo, a posse de escravos era um privilégio de uma minoria.

Tabela 1. Posse de escravos nos domicílios do Termo da Vila de São José (1831)

\begin{tabular}{|c|c|c|c|}
\hline Faixa de posse & No de posse & $\%$ & \% (excluídos domicílios sem escravos) \\
\hline Sem escravos & 2.799 & 60.8 & 21.13 \\
\hline 1 & 381 & 8.3 & 12.31 \\
\hline 2 & 222 & 4.8 & 27.95 \\
\hline $3-5$ & 504 & 11 & 18.86 \\
\hline $6-10$ & 340 & 7.4 & 12.59 \\
\hline $11-20$ & 227 & 4.9 & 3.38 \\
\hline $21-30$ & 61 & 1.3 & 3.77 \\
\hline Acima de 30 & 68 & 1.5 & 100 \\
\hline Total & 4.602 & 100 & \\
\hline
\end{tabular}

Autoria: Viviane P. C. Silva Ameno (software SPSS - Statistical Package for the Social Sciences) Fonte: NPHED - CEDEPLAR/UFMG, banco de dados das Listas Nominativas da década de 1830

Considera-se aqui, seguindo a divisão de Douglas Libby, quatro tamanhos de posse: "pequenas", de um a cinco escravos; "médias", de seis a dez escravos; "média grande", de onze a trinta escravos; e "grandes", mais de trinta escravos. ${ }^{17} 0$ percentual de $80.25 \%$ dos escravos sob posse de pequenos e médios proprietários revela que a posse de escravos era difundida naquela sociedade e, por conseguinte, havia ali certa desconcentração de riqueza. Contudo, é a associação entre cada categoria de posse e a proporção de escravos em cada uma delas que completa a visão da estrutura de

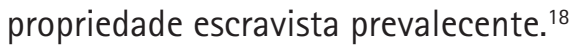

Tabela 2. Distribuição da escravaria por faixa de posse no Termo da Vila de São José (1831)

\begin{tabular}{|c|c|c|}
\hline Faixa de posse & No de escravos & $\%$ \\
\hline 1 & 381 & 2.8 \\
\hline 2 & 444 & 3.3 \\
\hline $3-5$ & 1.945 & 14.4 \\
\hline $6-10$ & 2.604 & 19.3 \\
\hline $11-20$ & 3.259 & 24.1 \\
\hline $21-30$ & 1.530 & 11.3 \\
\hline Acima de 30 & 3.360 & 24.8 \\
\hline Total & 13.523 & 100 \\
\hline
\end{tabular}

Autoria: Viviane P. C. Silva Ameno (software SPSS - Statistical Package for the Social Sciences) Fonte: NPHED - CEDEPLAR/UFMG, banco de dados das Listas Nominativas da década de 1830 
Ora, as faixas de posse "média grande" e "grande" somavam juntas 359 posses, ou 19,25\% do total dos escravistas, reunindo o número de 8149 escravos; enquanto as "pequenas" e "médias", totalizando 1447 posses mais que o triplo de posses do primeiro grupo - detinham conjuntamente apenas 5374 escravos. Para que a desconcentração de riquezas se confirmasse, o plantel de escravos de cada um desses grupos deveria guardar entre si medida mais equilibrada. Porém, as 359 posses "grandes" concentravam $60.2 \%$ dos escravos do termo, restando para os pequenos e médios proprietários, donos de 1447 posses, 39.8\% dos cativos. Conforme Clotilde Paiva ${ }^{19}$, nas regiões mais desenvolvidas, como era o caso da Intermediária PitanguiTamanduá, onde estava inserido o Termo de São José, o plantel de escravos estava segmentado de maneira mais ou menos equilibrada entre os grupos citados, dai a importância de uma análise mais individualizada do espaço aqui relacionado: o Termo de São José segundo exame particularizado não estava, nesse quesito, padronizado com sua Região. 0 interessante neste estudo é saber que boa parte dos jurados desse termo, figuravam não só entre os privilegiados indivíduos proprietários, mas faziam parte do seleto grupo daqueles que se enquadravam nas faixas "média grande" e "grande" de posses de escravos. É o que se discutirá mais adiante.

Para compor o perfil ocupacional da população do Termo de São José o melhor índice informativo trazido pela lista nominativa refere-se às atividades dos chefes dos fogos. Dentre elas destaco os três principais setores ocupacionais: 0 agropecuarista, as atividades manuais e mecânicas e 0 comércio. Pela tabela 3 observa-se onde estavam concentrados os principais esforços produtivos dos fogos, uma vez que, neles, eram empreendidas outras atividades paralelas e complementadoras da renda domiciliar. Além disso, os dados revelam como se dava a utilização da mão de obra escrava e livre nos domicilios sanjoseenses.

Tabela 3. Distribuição da população livre e escrava segundo ocupação do chefe de fogo

Termo da Vila de São José (1831)

\begin{tabular}{|c|c|c|c|c|}
\hline \multirow{2}{*}{ Setor de ocupação do Chefe de fogo } & \multicolumn{2}{|c|}{ Livres } & \multicolumn{2}{c|}{ Escravos } \\
\cline { 2 - 5 } & $\mathrm{N}^{\circ}$ & $\%$ & $\mathrm{~N}^{\circ}$ & $\%$ \\
\hline Não informado & 3.303 & $16.9 \%$ & 1.872 & $14 \%$ \\
\hline Agropecuária & 7.176 & $36.7 \%$ & 8.505 & $62.8 \%$ \\
\hline Mineração & 276 & $1.4 \%$ & 325 & $2.4 \%$ \\
\hline Atividades Manuais e Mecânicas & 4.841 & $24.8 \%$ & 1.119 & $8.3 \%$ \\
\hline Comércio & 1.362 & $7 \%$ & 1.026 & $7.6 \%$ \\
\hline Serviços Domésticos & 30 & $0.1 \%$ & 6 & $0 \%$ \\
\hline Funcionário Público & 218 & $1.1 \%$ & 368 & $2.7 \%$ \\
\hline Associações Ocupacionais & 2.179 & $11.2 \%$ & 296 & $2.2 \%$ \\
\hline Sem Ocupação & 159 & $0.8 \%$ & 6 & $0 \%$ \\
\hline Total & 19.544 & $100 \%$ & 13.523 & $100 \%$ \\
\hline
\end{tabular}

Autoria: Carlos de Oliveira Malaquias (software SPSS - Statistical Package for the Social Sciences) Fonte: NPHED - CEDEPLAR/UFMG, banco de dados das Listas Nominativas da década de 1830

No Termo de São José, o setor agropecuarista era aquele que mais concentrava trabalhadores, tanto livres quanto escravos. Conforme consideração de Douglas Libby, esse setor "era o virtual baluarte da economia de 
22

Ibidem.

23

Ibidem.

24

Ibidem, p.106.

25

Ibidem, p.109.

Ibidem.

27

A essa época, no sistema de eleição indireta do Império, os eleitores eram os indivíduos que haviam sido escolhidos nas eleições paroquiais para eleger os políticos que atuariam no âmbito provincial e nacional. Podia ser eleitor o indivíduo maior de 25 anos, livre e possuidor de renda anual de duzentos mil réis. BRASIL. Constituição (1824). Constituição Política do Império do Brasil, 1824. Biblioteca Digital Câmara. Das Eleições, p.11-13. Disponivel em: < http://bd.camara.gov.br>. Acesso em: 16/03/2012.

Minas dos oitocentos"20. As unidades produtivas dedicadas aos trabalhos

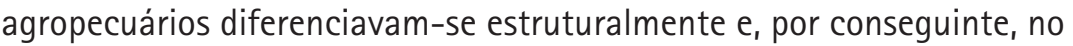
âmbito de suas incursões mercadológicas. No cenário em vista, podiam-se observar tanto pequenas unidades produtivas - onde os cuidados com a criação e plantação ficavam a cargo dos braços familiares, pois as possessões de escravos, quando existentes ali, eram modestas -, quanto "grandes unidades escravistas de alimentos, dotadas de largas escravarias e do virtual monopólio das terras"21. As primeiras, com áreas restritas e produções limitadas - retirando o necessário para o autoconsumo - comercializavam o excedente, "provavelmente abasteciam o mercado local e sustentavam os ranchos de parada de tropeiros e vendas de beira de estrada"22. As segundas "tinham participação predominante no comércio de abastecimento de longa distância"23. Entre os escravos, as atividades agropecuaristas eram, de longe, as que mais absorviam sua mão de obra, ao passo que a distribuição dos livres se dava de maneira mais diversificada em outras ocupações.

Nas atividades manuais e mecânicas, segundo setor em agrupamento de trabalhadores, o número de artesãos livres era três vezes maior do que 0 de escravos. A indicação se dirige a algumas possiveis inferências: "em São José esse seguimento era pouco dependente do trabalho escravo, e certamente menos dependente dessa mão de obra do que a agropecuária"24. Esses chefes artesãos, em sua maioria, tinham posses pequenas de escravos. Tal fato não necessariamente denota a retenção de poucos recursos. 0 mesmo pode ser imputado às atividades do comércio, onde a distribuição de livres e escravos se equivaliam. De acordo com Carlos Malaquias, os chefes de fogo do setor "era um grupo capitalizado, capaz de adquirir escravos, embora nem sempre fosse necessário muitos deles"25. Assim, a participação dos escravos na condução das tropas era maior do que na lida das casas de negócio, impedindo que procedessem com dinheiro e com as negociações comerciais. A parte da população do Termo de São José que era ligada ao setor de comércio, se analisada em relação ao todo, não parece, à primeira vista, representar papel importante, especialmente considerando-se a vocação produtora/exportadora da comarca em que estava inserida. Uma ponderação de Carlos Malaquias, porém, relativiza tal realidade. Como esclarece, "a circulação de bens e mercadorias na sociedade mineira do passado não era desconectada dos setores produtivos (...); negociantes e produtores muitas vezes vendiam e transportavam a produção do seu próprio fogo"26. Dito isso, é possivel que a inclusão de sujeitos no setor agropecuarista encobrisse sua participação nas atividades vinculadas ao comércio.

\section{Regulamentações dos trabalhos do júri}

0 Código do Processo Criminal de 1832 tratou das várias disposições referentes às pessoas encarregadas da administração da justiça criminal nos juizos de primeira instância; entre elas, os jurados. Segundo determinava o código, os eleitores ${ }^{27}$ eram os indivíduos habilitados a servirem no júri. Cada termo, ou julgado, contava com seu próprio conselho de jurados para resolução dos litígios criminais. Uma relação anual das pessoas em circunstâncias de participar do júri era feita, no termo, a partir de listas parciais elaboradas em seus distritos por juntas compostas por juizes de paz, párocos e presidentes das câmaras municipais. Na câmara municipal, os nomes alistados eram colocados em pequenas cédulas que, após serem lidas publicamente, eram lançadas em uma urna conservada, na sala de 
28

Código do Processo Criminal de Primeira Instância do Império Do Brasil augmentado com a Lei de 3 de dezembro de 1841 e seus regulamentos e disposição provisória. Josino Nascimento Silva. $5^{\text {a }}$ ed. Tomo I. Rio de Janeiro: Eduardo e Henrique Laemmert, 1864. p.33-40.

29

NEQUETE, Lenine. Op. Cit., p.51. Esse trabalho ganhou, em 1972, o prêmio Desembargador André da Rocha. Ainda hoje é referência para os estudiosos da justiça brasileira.

30

Sujeitos que moravam com os pais e deles dependiam economicamente. BRASIL. Constituição (1824). Constituição Política do Império do Brasil, 1824. Biblioteca Digital Câmara. Das Eleições, p.12. Disponivel em: < http:// bd.camara.gov.br>. Acesso em: 16/03/2012. sessões, fechada à chave. 0 juiz de direito era quem oficiava ao presidente da câmara - ou ao juiz de paz da cabeça do termo -, o dia e a hora em que as sessões do júri ocorreriam. Essa participação deveria considerar o tempo necessário para que os jurados e habitantes de todo o termo fossem comunicados. No dia seguinte à participação do juiz de direito, o presidente da câmara municipal, em presença dos vereadores, e a portas abertas, extraía da urna 60 cédulas para a formação do júri que serviria na sessão requerida. Essas cédulas eram fechadas em urna separada. Nos lugares mais públicos das cidades, vilas e povoados, eram lidas e afixadas as notícias sobre a próxima sessão. Além disso, os juízes de paz de todo o termo notificavam os jurados, os acusados e as testemunhas de seus respectivos distritos. No dia marcado, principiada a sessão, o juiz de direito abria a urna publicamente e verificava se ela continha as 60 cédulas com o nome dos convocados e as recolhia novamente. Após a chamada dos jurados e, achando-se completo o número legal - 48 jurados -, um menino extraía da urna 23 cédulas com os nomes daqueles que formariam o primeiro conseIho, ou júri de acusação. 0 juiz de direito deferia o juramento ao conselho e entregava todos os processos que haveriam de ser julgados. Os jurados, então, eram dirigidos a outra sala, onde, a sós e a portas fechadas, nomeavam por voto secreto seu presidente e secretário. Após conferenciarem sobre cada processo, deliberavam se havia ou não matéria para acusação dos réus processados. Se a decisão fosse negativa, o juiz de direito, por sua sentença lançada nos autos, julgaria de nenhum efeito a queixa ou denúncia. Se, ao contrário, o júri achasse matéria para acusação do réu, o juiz ordenava sua custódia e ele seria acusado perante o júri de sentença. Guardadas todas as formalidades que estavam prescritas para a formação do primeiro conselho, o segundo, formado por doze jurados, reunia-se para sentenciar a favor ou contra o acusado. No Termo de São José, conforme exigia o código de processo, o conselho de jurados se reunia duas vezes por ano. As sessões duravam quinze dias sucessivos, mas tal prazo poderia se prorrogar, ainda, por três a oito dias. Nessas sessões, decidiam-se todos os processos competentemente preparados pelos juizes de paz do termo. Essencialmente, essas eram as disposições legais do código de processo que orientavam o funcionamento do júri. ${ }^{28}$

O Conselho de jurados do Termo de São José: composição e atuação Resta saber quem eram as pessoas que participaram como jurados no tribunal de São José, quais crimes estiveram sob suas apreciações e como julgaram. As respostas a essas questões iluminam algumas ponderações sobre a consideração de Lenine Nequete a respeito do código de processos. Segundo ele, o código propôs uma organização judiciária "inteiramente nova, na qual predominava o princípio do julgamento do acusado pelos seus pares reunidos em conselho e formando o júri" ${ }^{29}$.

Como já mencionado, o júri se formava pelos indivíduos que reuniam as condições para serem eleitores. É notório que os artigos concernentes às eleições na Constituição de 1824 se estipulassem por meio das exclusões, pois a maior parte da população não participaria delas. Estavam excluídos das votações de paróquia as mulheres, os menores de 25 anos, os filhos familias ${ }^{30}$, os religiosos enclausurados e aqueles que não tivessem renda anual de cem mil réis. Segundo o artigo 94 da Constituição, os eleitores compreendiam os indivíduos que pudessem votar na Assembléia Paroquial, excetuando-se os que não tivessem renda líquida anual de duzentos mil 
Na verdade, se considerarmos a existência dos juízes ordinários sua assertiva é também problemática, pois os juizes ordinários - sem formação em direito - já atuavam na justiça colonial. Ou seja, leigos atuando na justiça não era uma realidade inteiramente nova.

33

A setorização ocupacional foi feita conforme Clotilde Paiva e a divisão de posses segundo Douglas Libby.

34

LIBBY, Douglas. Op. Cit., p.97. réis, os libertos e os criminosos pronunciados em querela, ou devassa. ${ }^{31}$ Dado que o júri se formava por eleitores, e esses, nas próprias prescrições constitucionais, se conformavam em um grupo restrito, fica evidente que 0 princípio do julgamento dos acusados pelos seus pares não era, em muitos casos, uma verdade, salvo se essa noção dissesse respeito ao exercício do julgamento por leigos. Ou seja, se o autor estivesse apontando a abertura da possibilidade da justiça feita por meio de juízes não profissionais. Se, entretanto, não fosse essa a ideia de Nequete sua assertiva é problemática, pois, em muitos julgamentos, não havia entre jurados e réus equidade socioeconômica. ${ }^{32}$ Ainda que se pudesse atribuir ao júri de São José uma postura imparcial, a exclusão de forros, escravos, mulheres e pobres livres (minoritariamente representados) do conselho invalida a noção de julgamento pelos pares, já que esses grupos figuravam como réus nos tribunais. Assim, o princípio do julgamento dos acusados por seus pares só tinha sentido verdadeiro quando o réu em juízo possuía condição social equiparada ao dos jurados.

As tabelas a seguir demonstram como se compunha o júri de São José. A exposição desses dados é um procedimento metodológico que teve como objetivo a identificação socioeconômica dos jurados, para tanto, dois dados foram utilizados: suas ocupações e o número de escravos que possuiam. ${ }^{33}$ Desse modo, toma-se como medida de riqueza a "mais básica forma de propriedade do regime escravista, o escravo" ${ }^{\prime 3}$, associada a verificação dos setores produtivos em que os jurados estavam inseridos, visto que atividades lucrativas podiam não estar relacionadas à posse de cativos.

Tabela 4. Ocupação dos jurados do Termo de São José na década de 1830

\begin{tabular}{|c|c|c|}
\hline Setor ocupacional & Número de jurados & $\%$ \\
\hline Sem informação & 11 & 6.5 \\
\hline Agropecuária & 91 & 53.5 \\
\hline Atividade manual/ mecânica (madeira) & 3 & 1.8 \\
\hline Atividade manual/mecânica (metais) & 2 & 1.2 \\
\hline Atividade manual/mecânica (couros e peles) & 4 & 2.3 \\
\hline Comerciante fixo & 33 & 19.5 \\
\hline Funcionário público & 13 & 7.6 \\
\hline Associações ocupacionais & 13 & 7.6 \\
\hline Total & 170 & 100 \\
\hline
\end{tabular}

Autoria: Carlos de Oliveira Malaquias (software SPSS - Statistical Package for the Social Sciences) Fonte: NPHED - CEDEPLAR/UFMG, banco de dados das Listas Nominativas da década de 1830 / Processos Criminais do Fórum de Oliveira 1832-1841 (Sob Guarda: UFSJ/LABD0C)

Pode-se observar pela tabela 4 que a concentração de jurados se dava justamente na atividade produtiva mais dinâmica do termo, a agropecuária. Enquanto, esse setor, para todo o Termo de São José, abarcava cerca de $1 / 3$ da mão de obra livre, sua abrangência, no júri, atingia mais da metade do grupo. A média de jurados no setor de comércio é bem maior do que a verificada no termo, as somas revelam uma amostra quase três vezes mais elevada. Mais surpreendentes são os números para o funcionalismo público: a porção de jurados nessa ocupação é de $7.6 \%$, ao passo que no termo ela é de $1.1 \%$. A parcela do júri nas atividades 
35

MALAQUIAS, Carlos de Oliveira. Op. Cit., p.106.

36

Essas comparações foram realizadas a partir dos dados da tabela 3. A comparação se fez entre os indivíduos livres - condição necessária para a atuação no júri. manuais e mecânicas é menos representativa do que a do termo: 5.3\% contra $24.8 \%$ respectivamente. É sabido, que eram pequenas as posses de escravos entre artesãos, quando existiam. "Em mais de quatro quintos das unidades produtivas de transformação, o trabalho dependia de braços livres" 35 . Donde se infere - utilizando os escravos como medida de riqueza - que as atividades artesanais eram desempenhadas, sobretudo, por pessoas de situação econômica modesta. É significativa a pouca representatividade do júri nesse setor, pois ela é indício de que o conselho de São José se formava pelos abastados daquela sociedade. ${ }^{36} \mathrm{~A}$ tabela 5 confirma esse sinal.

Tabela 5. Posse de escravos entre os jurados do Termo de São José na década de 1830

\begin{tabular}{|c|c|c|c|}
\hline Faixa de Posse & Número de jurados & $\%$ & \% acumulada (faixa posse) \\
\hline Sem escravos & 5 & 2.9 & 2.9 \\
\hline 1 & 10 & 5.9 & \\
\hline 2 & 15 & 8.8 & 37.6 \\
\hline $3-5$ & 39 & 22.9 & 20.6 \\
\hline $6-10$ & 35 & 20.6 & \\
\hline $11-20$ & 34 & 20 & 25.3 \\
\hline $21-30$ & 9 & 5.3 & 13.6 \\
\hline Mais de 30 & 23 & 13.6 & 100 \\
\hline Total & 170 & 100 & \\
\hline
\end{tabular}

Autoria: Carlos de Oliveira Malaquias (software SPSS - Statistical Package for the Social Sciences) Fonte: NPHED - CEDEPLAR/UFMG, banco de dados das Listas Nominativas da década de 1830 / Processos Criminais do Fórum de Oliveira 1832-1841 (Sob Guarda: UFSJ/LABDOC)

A escravaria de todo o termo dividia-se entre $39.2 \%$ dos fogos sanjoseenses. A equivalência de jurados proprietários, por sua vez, era de $97.1 \%$. No júri, 38,9 \% de seus membros eram donos de plantéis com mais de 11 escravos, posses que, à época, eram diferenciadas. Esse número expressivo, contudo, contrapõe-se a soma de $37.6 \%$ de pequenas posses matizando uma heterogeneidade no conselho de São José. As médias posses (6-10 escravos), controladas por 20.6\% dos jurados, se tomadas segundo concepção de Douglas Libby, emprestariam ao conselho uma configuração mais elitista. Para o historiador, os médios proprietários estavam inseridos na elite local: "os médios e grandes proprietários formam a elite local do regime escravista, e é entre eles que certamente se identificaria a quase totalidade dos votantes e eleitores da restrita política eleitoral que marca o período" ${ }^{137}$. Sob este ponto de vista, dos 170 jurados levantados 101 eram detentores de "média" e "grande" posses de escravos e faziam parte, então, da elite sanjoseense. Daí se conclui que a maioria dos jurados não só figurava como parte da minoria de proprietários, mas inseria-se no restrito grupo de proprietários com as maiores escravarias do termo.

A tabela 6 apresenta a distribuição da escravaria segundo os setores ocupacionais em que atuavam os jurados. 
Os perfis traçados nessa página e nas duas seguintes, relativos aos dados socioeconômicos dos jurados, foram elaborados a partir do cruzamento dos Processos Criminais do Fórum de Oliveira e das Listas Nominativas de 1831 e 1838. É inviável citar exatamente os processos em que esses jurados aparecem, uma vez que, muitos deles, participavam da apreciação de vários crimes numa mesma sessão e, até mesmo, em sessões posteriores. Ao todo são 41 processos iniciados entre os anos de 1832 e 1841.
Tabela 6. Posse de escravos dos jurados segundo ocupação - Termo de São José / década de 1830

\begin{tabular}{|c|c|c|c|c|c|c|c|c|c|}
\hline $\begin{array}{c}\text { Setor } \\
\text { Ocupacional }\end{array}$ & \multicolumn{10}{|c|}{ Faixa de posse } \\
\hline & s/escravo & $\%$ & 1 ou 2 & $\%$ & 3 a 10 & $\%$ & 11 ou + & $\%$ & Total \\
\hline Agropecuária & 1 & 1.1 & 8 & 8.8 & 39 & 42.9 & 43 & 47.2 & 91 \\
\hline $\begin{array}{c}\text { Ativ.manual/ } \\
\text { mecânica }\end{array}$ & 2 & 22.2 & 1 & 11.1 & 6 & 66.7 & 0 & 0 & 9 \\
\hline $\begin{array}{c}\text { Comerciante } \\
\text { fixo }\end{array}$ & 0 & 0 & 9 & 27.3 & 15 & 45.4 & 9 & 27.3 & 33 \\
\hline $\begin{array}{c}\text { Funcionário } \\
\text { público }\end{array}$ & 0 & 0 & 2 & 15.4 & 7 & 53.9 & 4 & 30.8 & 13 \\
\hline $\begin{array}{c}\text { Associação } \\
\text { ocupacional }\end{array}$ & 2 & 15.4 & 4 & 30.8 & 3 & 22 & 4 & 30.8 & 13 \\
\hline Total & 5 & 3.1 & 24 & 15 & 70 & 44 & 60 & 37.7 & 159 \\
\hline
\end{tabular}

Autoria: Carlos de Oliveira Malaquias (software SPSS - Statistical Package for the Social Sciences) Fonte: NPHED - CEDEPLAR/UFMG, banco de dados das Listas Nominativas da década de 1830 / Processos Criminais do Fórum de Oliveira 1832-1841 (Sob Guarda: UFSJ/LABDOC) Nota: As percentagens somam 100 na horizontal.

Como anteriormente destacado, os jurados de São José ocupavamse, principalmente, no setor agropecuário. A informação adicional que a tabela 6 apresenta é o vislumbre do tipo de unidade produtiva pertencente aos jurados. A indicação é de que boa parte desses jurados (47.2\%) dedicava-se à administração de unidades agrícolas de maior escala, haja vista a elevada concentração de escravos que possuíam. Tais jurados, provavelmente, estiveram envolvidos com produções destinadas a mercantilização interprovincial. ${ }^{38}$

Entre os nove jurados artesãos, havia três sapateiros, um curtidor de couro, três carpinteiros, um ferreiro e um ourives. 0 jurado artífice de ourivesaria não possuía escravo. Tal fato pode relacionar-se ao tipo de material de trabalho dessa atividade e a especialização necessária ao seu exercício. 0 jurado ferreiro era também alferes e possuía cinco escravos. Todos os carpinteiros possuiam escravos e apresentavam posses modestas de um, quatro e cinco escravos. É provável, que o jurado curtidor de couro não exercesse tal ofício deixando os trabalhos para seus sete cativos. Entre os sapateiros, um não possuía escravo. Esse jurado assinava José Jacinto. A falta de sobrenome gera incerteza quanto a sua identificação. No entanto, ele não foi excluido, pois era livre e tinha idade compativel para o exercício do júri. José jacinto não se encaixa, entretanto, no perfil do conselho de São José, pois era pardo e não era chefe do domicilio em que morava. 0 júri formava-se majoritariamente por brancos e por chefes de fogos: 87,6 $\%$ eram brancos e $87 \%$ eram chefes.

Dentre os treze jurados funcionários públicos, destaca-se o grupo de eclesiásticos, que somavam nove indivíduos. Seis deles ou eram pardos ou não figuravam entre a chefia do domicílio; todavia eram detentores de numerosos escravos, dominando, inclusive, as duas maiores posses identificadas nesse júri: o padre José Maria Correia, pardo, chefe de seu domicílio em Prados, era de possuidor de 94 escravos. 0 eclesiástico Joaquim Gonçalves de Lara, branco, era parente do chefe do fogo. No domicílio onde habitava 
39

MALAQUIAS, Carlos de Oliveira. Op. Cit., p.110.

40

BUENO, José Antônio Pimenta. Direito público Brasileiro e Análise da Constituição do Império. Brasilia: Senado Federal, 1978. p.381.

41

MATTOS, Hebe Maria. Escravidão e Cidadania no Brasil Monárquico. Rio de Janeiro: Jorge Zahar, 2004. p.7.

42

0 sexto artigo da Constituição de 1824 previa: "são cidadãos brasileiros os que no Brasil tiverem nascido, quer sejam ingênuos, ou libertos (...)". Não há no texto qualquer menção ao forro africano, assim, por dedução, acredito que o escravo africano não era admitido como cidadão após a alforria. Sua admissão nas eleições primárias me parece ainda menos provável, ainda que tivesse renda para tal. BRASIL. Constituição (1824). Constituição Política do Império do Brasil, 1824. Biblioteca Digital Câmara. Das Eleições, p.1. Disponivel em: < http://bd.camara. gov.br>. Acesso em: 16/03/2012. na Vila de São José havia 74 escravos.

Pelo que indica a tabela 6 , existia, no júri, comerciantes de diferentes perfis e portes. 0 alcance de suas transações mercantis pode ser mensurado a partir da quantidade de escravos que possuiam. A situação econômica desse grupo, entretanto, é mais difícil de ser verificada, pois conforme esclarece Carlos Malaquias, era habitual que, nas casas de negócio, devido ao trato com o dinheiro e a natureza contábil da atividade, os comerciantes preferissem familiares ou contratados à mão de obra escrava. ${ }^{39}$ Nesse caso, o escravo não deve ser utilizado como medida de riqueza; melhor seria a investigação dos inventários e testamentos desses indivíduos. Alguns exemplos demonstram como os jurados comerciantes podiam diferenciar-se conforme a abrangência espacial de suas atividades. 0 carniceiro José Antônio de Melo era pardo e chefe de seu domicílio, possuía dois escravos. Como comerciante varejista sua pequena loja devia atender a demandas miúdas e aos estabelecimentos que abrigavam forasteiros. A venda do jurado Adriao Pereira Lagos, pardo, chefe de seu fogo e dono de três escravos tipificava-se pelas mesmas condições, focando-se no abastecimento do mercado doméstico. De outro lado estavam os negociantes brancos Manoel Rodrigues Chaves, com 35 escravos, e o senhor Jerônimo da Costa Guimarães com 42 escravos. Esses, certamente, eram comerciantes de maior envergadura que exportavam e importavam mercadorias extrapolando o espaço provincial.

A exposição desses dados mostra que o conselho de jurados do Termo de São José compunha-se por uma formação socioeconômica heterogênea, destacando-se, porém, um número significativo de indivíduos abastados. Em si mesmo, o modo como os jurados eram escolhidos não garantia a equidade entre as partes julgadoras e julgadas. 0 perfil desse júri foi traçado segundo as indicações seletivas da Constituição de 1824. 0 sistema de jurados conferia aos indivíduos dele participantes a prática de um direito político, o exercício da cidadania ativa. Os direitos políticos, de acordo com Pimenta Bueno "são filhos unicamente das leis ou constituições políticas, são criações das conveniências e condições destas, e não faculdades naturais" ${ }^{40}$. A regulação dos direitos políticos, como também dos direitos civis, refletia na Constituição as inconveniências de um pacto estabelecido dentro de um país recém-independente e de composição escravista.

A primeira carta constitucional brasileira seria marcada por um paradoxo atualmente irreconciliável: sob bases liberais, a constituição de 1824 "considerava todos os homens livres e iguais. Apesar disso, a escravidão permaneceu inalterada, garantida que era pelo direito de propriedade reconhecido na nova constituição" ${ }^{41}$. Aos contemporâneos, entretanto, tal paradoxo era contornável. Nele, regularizou-se o estabelecimento dos critérios para o exercício da cidadania. Os direitos civis estavam destinados a todos os brasileiros - os nascidos no Brasil e também aqueles que, de forma tácita ou explícita, aderissem à causa da independência. Nesse caso, estavam incluídos como cidadãos aqueles que possuíam ascendência africana, desde que livres. ${ }^{42}$ Esse conjunto populacional, por sua expressão numérica, fez com que o quadro de cidadãos brasileiros superasse os de não cidadãos (os escravos). 0 exercício da cidadania política, porém, não se estendeu tão largamente. Ele foi fixado em função da posse dos indivíduos. Aqueles que não possuiam renda suficiente para votar eram chamados cidadãos passivos. Inversamente, eram chamados ativos os cidadãos que tinham direito ao voto. Entre eles duas categorias se distinguiram censitariamente: os votantes e os eleitores e elegíveis. Existia para os brasileiros 
43

MATTOS, Hebe Maria. Op. Cit., p.23.

44

Ibidem, p.19-35.

45

ACANDA, Jorge Luis. Sociedade civil e hegemonia. Rio de janeiro: Editora UFRJ, 2006. p.81.

46

0 termo "magnatas" apresenta-se, aqui, tal qual encontrado no texto de Flory. excluídos da cidadania ativa a possibilidade de alcançar o foro de votante: o voto nas eleições primárias dependia do encalço de uma renda líquida anual de cem mil réis. Para o eleitorado, porém, as habilitações exigidas eram mais qualificadas: estavam excluídos os forros e a renda requerida era de duzentos mil réis.

Os graus de cidadania dispostos na Constituição informavam sobre uma questão muito delicada: como se legitimava, naquela sociedade, a diferença de direitos entre os livres, sobretudo, quando se pensa que os critérios de exclusão recaiam, principalmente, sobre a população não branca? É fato: a população livre "de cor" reivindicava o apagamento dessas diferenças. De acordo com Hebe Mattos "as questões dos direitos dos homens livres e de igualdade entre 'todas as cores de cidadãos' estiveram no centro de todas as mobilizações populares do período"43. A autora atenta para o fato de que a luta antidiscriminatória que tinha como pano de fundo a escravidão não trazia como proposição sua abolição imediata. Ao mesmo tempo, a justificativa para a permanência dessa instituição passava bem longe de explicações "racializadas". 0 princípio liberal de direito de propriedade era mais adequado a situação brasileira e potencialmente menos explosivo, visto que os indivíduos "de cor" contavam parcela significativa entre os brasileiros. ${ }^{44}$ De um lado, a propriedade apresentava-se como justificativa a permanência da escravidão, de outro, determinava as distinções de direitos. Assim, se a distribuição de direitos era determinada pela posse, então, caberia ao indivíduo - por seus talentos e virtudes - o encargo de conquistá-los. Evocava-se a idéia de que "por meio da propriedade o homem se converte em cidadão, em sujeito de direitos políticos"45. Mas afinal, quantos homens efetivariam tal conversão? Quão distante estavam os homens "de cor" de alcançar o direito de ser eleitor e, por consequência, de ser jurado? Lembrando alguns dados relativos ao Termo de São José, sabemos que quase 90\% dos jurados eram brancos (a soma dos brancos, na população total do termo, era de aproximadamente $30 \%)$. Se é certo que a cor não determinava o estado de riqueza ou pobreza dos indivíduos, tendo inclusive a historiografia vários exemplos de homens "de cor" abastados, não é menos exato que os critérios censitários recusavam, principalmente, a população de ascendência negra da cidadania ativa. Decididamente, o exercício do júri, regulado a partir do direito de eleger, era uma tarefa destinada, sobretudo, aos indivíduos da elite socioeconômica. A esse respeito existem controvérsias.

0 brasilianista Thomaz Flory, referência entre os acadêmicos, é autor de importante discussão sobre o funcionamento do júri no Brasil. Para ele, o sistema de jurados ambicionado pelos contemporâneos como garantia jurídica de independência local (que os afastaria da influência perniciosa da magistratura profissional dependente) mostrou-se frágil na efetivação de sua prática e diante das expectativas criadas pela ampliação de sua jurisdição. Na visão do autor, o júri foi apenas uma promessa de independência judicial não efetivada, pois seu funcionamento foi condicionado pelas vontades dos magnatas locais que exerciam o controle sobre a formação e as decisões da instituição. ${ }^{46} \mathrm{~A}$ estrutura popular do júri e a natureza da sociedade brasileira são apontadas como razões da vulnerabilidade dos jurados às influências externas. Em sua análise, o autor desloca o sentido de "popular" (juizes de fato) em oposição à "profissional" (magistrados instruídos na lei), imprimindo no termo uma conotação socioeconômica. Para ele, os sujeitos com perfil social necessário para serem "independentes" geralmente se evadiam dos deveres de jurado, deixando essa tarefa para as 
FLORY, Thomas. El Juez de Paz y el jurado em Brasil Imperial, 1808-1871. Control social y estabilidad política en el nuevo estado. México: Fondo de Cultura Económica, 1986. p.192-193.

48

Quando Flory faz alusão aos magnatas locais parece-me que ele está se referindo a elite socioeconômica de maneira ampla e não aos indivíduos que dentro desse grupo poderiam ser denominados também de potentados. Se entre o conselho de jurados do Termo de São José existiram potentados, homens influentes politicamente que atuaram a favor ou contra o poder estatal, eu não saberia dizer, a análise aqui empreendida é mais geral, indica o perfil do júri e não dos jurados individualmente.

49

FRANCO, Maria Sylvia de Carvalho. Homens Livres na Ordem Escravocrata. São Paulo: Unesp, 1997. p.162.

50

Ibidem, p.161.

51

RESENDE, Edna Maria. Entre a Solidariedade e a Violência: Valores, comportamentos e a lei em São João del Rei, 1840-1860. São Paulo: Annablume; Belo Horizonte: PPGH/UFMG, Barbacena: UNIPAC, 2008. classes sociais mais suscetíveis ao suborno e às pressões de autoridades. 0 autor acredita que a vulnerabilidade do júri o tornava indulgente com os acusados, favorecendo-os com deliberações de absolvição e corroborando com a impunidade na justiça. ${ }^{47}$

As considerações de Thomaz Flory contrariam a principal defesa até aqui apresentada, a ideia de que o júri era formado majoritariamente pela elite. Além disso, o autor aborda uma questão muito difundida em relação ao júri: o excessivo número de absolvições nos julgamentos dos jurados. É preciso destacar que a interpretação de Flory foi elaborada, principalmente, por meio de indicações de jornais das décadas de trinta e quarenta dos oitocentos. 0 autor não abordou uma região específica onde o júri funcionou e nem trabalhou diretamente com fontes criminais.

0 levantamento dos dados aqui apresentados relativos ao conselho de jurados do Termo de São José demonstra que sujeitos independentes exerceram o serviço do júri, pelo menos na primeira década de funcionamento da instituição. Esse júri constituía-se essencialmente por homens brancos, chefes de seus domicílios e com posição econômica destacada nas várias ocupações em que atuavam. É verdade que os magnatas controlaram as decisões da instituição, não poderia ser diferente. 0 júri era formado por magnatas, logo os sentenciamentos se conformavam às suas análises. ${ }^{48}$ Quanto ao controle da formação do conselho, é preciso refletir sobre a viabilidade dessa situação. 0 Termo de São José compunha-se por 21 distritos. Para que um júri fosse forjado seria necessária uma difícil articulação que levasse em conta 0 alistamento dos jurados em todos os termos, o sorteio dos jurados de acusação e sentença, o deslocamento e a presença de cada um deles na sessão de julgamento - marcada exclusivamente pelo juiz de direito - e a acomodação dos interesses dos diversos grupos influenciadores dentro do júri.

Relativamente às absolvições, o júri aqui analisado também não corresponde à caracterização de Flory. Não só por que se refuta a ideia de um júri vulnerável e propenso aos desmandos das autoridades locais, mas pela razão de o conselho de São José ter achado matéria para acusação de todos os réus postos sob julgamento (se assim não procedessem, a queixa ou denúncia seria julgada sem efeito e o processo imediatamente se finalizaria). Tal fato contesta, igualmente, outra ótica, já clássica, relativa ao funcionamento do júri, os apontamentos de Maria Sylvia de Carvalho Franco. Para a autora, a reputação de negligência adquirida pelo júri e a falta de rigor de seus sentenciamentos não se ligam, como em Flory, à constituição social das pessoas que o formavam, mas à falta de um "adestramento intelectual que as tornasse aptas a conduzir sua reflexão de acordo com os princípios do direito" ${ }^{49}$. Sistematicamente, os jurados orientavam-se por normas morais, numa sociedade que tinha a violência como a própria moralidade. Assim, a incidência regular de veredictos favoráveis aos réus é explicada pela "existência de um código de valores a orientar metodicamente as decisões dos jurados num rumo muito diverso daquele que assumiriam se estivessem norteados pelos códigos de direito"50.

A mesma perspectiva sobre 0 assunto é focalizada por Edna Maria Resende. ${ }^{51}$ Para ela, os jurados percebiam a lei como uma formalidade vazia de significação e julgavam as condutas e as ações dos réus norteados pelos padrões de moralidade da comunidade em que viviam; e, compartilhando os valores dos acusados, aceitavam as justificações dos réus para seus atos, que não eram vistos como criminosos.

É preciso problematizar a relação apresentada entre absolvições, 
Ler e escrever eram qualidades às quais estavam obrigados apenas dois jurados: aquele que presidiria a sessão e aquele que iria secretariá-la.

53

VELLASCO, Ivan de Andrade. As Seduções da Ordem: Violência, criminalidade e administração da justiça: Minas Gerais - século XIX. São Paulo: EDUSC/ANPOCS, 2004. p.144.
54

Fala dirigida à Assembléia Legislativa Provincial de Minas Gerais na sessão ordinária, do ano de 1837, pelo presidente da província Antonio Costa Pinto. Ouro Preto, Typografia do Universal, 1837. Disponivel em: www.crl.edu. Acesso em: 28/04/2011. normas morais e normas jurídicas em pelo menos três aspectos. Em primeiro lugar, o júri não se comprometeria se conduzisse sua atuação baseada por normas morais, uma vez que a própria Constituição de 1824 assim o determinava no Título $\mathrm{VI}$, capítulo único, artigo 152: "Os jurados pronunciam sobre o fato, e os juízes aplicam a lei". Ora, os jurados não eram instruidos nas leis, nem ao menos thes era exigida a qualidade de saber ler e escrever. ${ }^{52}$ Esperava-se dos jurados, aliás, dos juízes de fato, bom senso e honradez na apreciação do fato ocorrido, julgando segundo suas consciências - sua moral -, sem necessidade de fundamentar suas decisões.

Em segundo lugar, é necessário refletir sobre as críticas feitas a atuação do júri, sobretudo, sobre as indicações de que sentenciavam desapropriadamente. Deve-se ter em vista quem foram os contemporâneos que os criticaram. Ivan Vellasco, em análise referente às absolvições e condenações dadas pelo júri na Comarca do Rio das Mortes, escreveu que "as coisas não iam tão mal" quanto apontava as críticas à instituição. Para ele as queixas assumiram ares de uma campanha pelo progressivo esvaziamento do sistema de jurados. ${ }^{53}$ É necessário, assim, verificar em que medida o desconforto em relação ao júri se fez por motivos políticos. A ampliação da competência do júri não era uma ideia sustentada por todos os legisladores e aqueles a quem representavam; houve, a seu respeito, resistências de nuanças variadas. A verdade é que, à época, as considerações feitas sobre o júri não se baseavam em levantamentos sistemáticos de dados comparativos sobre a instituição após o início da execução do Código do Processo. Foi o que relatou o presidente de província de Minas no ano de 1837:

\begin{abstract}
Não existindo na secretária documentos que tornem palpáveis os efeitos que anualmente tem produzido a execução dos dois códigos, criminal e do processo, não é possivel emitir-se uma opinião segura sobre o movimento de moralidade, e eficaz repressão dos delitos. Estes dados só se podem obter de estatísticas criminais, organizadas todos os anos, para servirem umas as outras de termos de comparação. Trabalhos desta natureza exigidos pela primeira vez dos juizes de direito, servirão para organizar-se o mapa junto, que mostra, não os crimes perpetrados durante o ano próximo passado, mas aqueles que foram submetidos a consideração do júri. ${ }^{54}$
\end{abstract}

De mais a mais, entre os contemporâneos as opiniões sobre o sistema de jurados eram desencontradas. Nesta mesma fala do presidente Antonio Carlos Pinto ele mencionou um parecer favorável ao júri dado por juízes de direito, justamente aqueles apontados, por contemporâneos e estudiosos, como os mais minados pela reforma judiciária e o alargamento da jurisdição do júri. Disse o presidente:

Segundo a opinião dos juízes de direito, desenvolvida nos relatórios dos trabalhos do júri, enviados a governo central, por intermédio da presidência, os jurados de muitos termos conduzem-se com dignidade, circunspecção e inteireza, e se aberram algumas vezes do exato cumprimento de seus deveres, isso nada depõem contra a instituição (que nesta província não há de certamente cair em descrédito) por quanto em todos os tempos e lugares semelhantes faltas podem ser mais ou menos cometidas, visto que ao erro é sujeita a fraca humana condição. ${ }^{55}$

De outro lado, pode-se encontrar no Astro de Minas, jornal liberal moderado sanjoanense, críticas graves a instituição, de onde, por suposição, se esperava um posicionamento mais transigente em relação ao sistema de jurados: 
Astro de Minas, São João del-Rei, 07 de abril de 1835, n. 1152.

57

FRANCO, Maria Sylvia de Carvalho. Op. Cit., p.166.

58

Ibidem, p.164.

59

BOURDIEU, Pierre. O Poder Simbólico. Rio de Janeiro: Bertrand, 2009. p.243.
0 júri (forçoso é dizê-lo) não tem correspondido no Brasil de esperanças que nessa instituição haviam depositado. (...) 0 primeiro e lamentável inconveniente é a inércia: em algumas vilas e cidades, o júri não tem se reunido, porque os seus membros deixaram de concorrer, (...) parece que os nossos compatriotas ainda não apreciam toda a excelência do direito que os constitui juizes uns dos outros e os subtrai ao domínio de qualquer classe ou hierarquia. Aparece logo depois uma falsa piedade que induz os jurados a perdoar, ainda mesmo quando a seus olhos está provado o delito. ${ }^{56}$

$E$, finalmente, em terceiro lugar, cabe o debate sobre a inabilidade dos jurados com as novas regras legais. Para o conselho do Termo de São José, tal concepção é discutivel. Se a eles faltava um adestramento intelectual que os tornassem aptos a conduzirem suas reflexões de acordo com os princípios do direito, o que explica o fato de que, em todos os processos-crime analisados nessa pesquisa, o primeiro conselho de jurados tenha achado matéria para acusação de todos os réus? Ora, o júri de São José verificou a materialidade - conjunto de elementos objetivos que caracterizam uma contravenção - dos crimes apresentados a eles em sessão de julgamento, o que implica que se ajustavam as orientações penais do novo código penal. Nesse caso, é preciso refletir sobre a possibilidade de que os jurados julgaram a partir de uma racionalidade que ia além de uma moralidade violenta. E mais, é válido considerar que não só o júri, mas aquela comunidade - ou parte dela - em alguma medida aderiu às novas orientações da justiça e do direito brasileiro, pois buscaram resolver seus conflitos juridicamente.

As indagações e reflexões sobre a instituição do júri neste estudo refletem um posicionamento teórico que não crê no exercício do direito como uma fachada legal que é instrumentalizada para firmar o controle do Estado sobre a população em geral, ou que sempre está destinado a favorecer um potentado local e seus aliados. Se a justiça muitas vezes esteve a serviço dessas forças, não é menos verdade que ela também foi cenário de atuação mesmo para aqueles que ocuparam os últimos lugares da hierarquia social. Dai surge o desencontro entre as convicções aqui expressas e as de Maria Sylvia que supõe o "uso do aparelho do governo como propriedade privada"57. Para a autora, a justiça estatal representava para os dominados "uma longínqua, desconhecida e temida organização"58, e por isso, prevaleceu entre eles o uso da violência na resolução de seus conflitos: não substituiram esses atos "imediatos e eficazes" pelas providências estatais no âmbito jurídico.

Conforma-se aqui com a historiografia que, desde os anos 80 , tem revisto o tema da justiça identificado como instrumento de dominação. Não se trata de desconsiderar que os textos jurídicos, e o ordenamento social que deles advêm, sejam adequados aos valores dos dominantes, mas discute-se a falta de relativização daquele ponto de vista. A eficácia do direito se inscreve na convicção, mais ou menos explícita, que ele foi produzido em coautoria pelos legisladores e pela sociedade. 0 direito "não pode exercer-se senão com a cumplicidade daqueles que o suportam" ${ }^{\text {"59 }}$. A revisão historiográfica possibilitou um alargamento quanto à compreensão dos usos do direito, retirando-lhe o pressuposto de que as ações na justiça seriam sempre desfavoráveis aos dominados. Novas discussões se estabeleceram a partir do entendimento da justiça como um campo de possibilidades, ou um campo de lutas, como indica Ivan Vellasco:

A justiça conforma um campo de lutas, cuja especificidade é dada pela construção de uma forma de dominação legal, que impõe limites aos grupos dominantes e 
60

VELLASCO, Ivan. As Seduções da Ordem..., Op. Cit., p.223.

61

LARA, Silvia Hunold. Campos da Violência: escravos e senhores na capitania do Rio de Janeiro, 1750-1808. Rio de Janeiro: Paz e Terra, 1988.

62

BOURDIEU, Pierre. Op. Cit., p.243.

63

GRINBERG, Keila. Liberata, a lei da ambiguidade: as ações de liberdade na Corte de Apelação do Rio de Janeiro, século XIX. Rio de Janeiro: Relume-dumará, 1994.

64

VELLASCO, Ivan. Os Predicativos da Ordem: os usos sociais da justiça nas Minas Gerais 17801840. Revista Brasileira de História, vol. 25, n.50, p.182, jul-dez de 2005.

65

Ibidem, p.223

66

BOURDIEU, Pierre. Op. Cit., p.229. subordina a todos, ainda que em uma sociedade fortemente hierarquizada e apesar das diferenças e assimetrias de exposição e acesso às suas instituições e seus benefícios. Sua existência, como um campo de forças, inicia um capítulo de lutas pela justiça nas quais os diversos setores sociais participam e representam seu papel; e cujo resultado não é previamente dado. ${ }^{60}$

A historiografia ligada à escravidão tem um papel importante nessa reformulação teórica. Silvia Lara ${ }^{61}$ apresentou uma discussão interessante sobre a economia do castigo no sistema escravista no século XVIII, apontando a impossibilidade de se conceber o direito sob aspectos rígidos, uma vez que o acionamento da lei dá-se conforme diferentes intenções. Os rigores das normas, então, ganham flexibilidade no cotidiano da vida. Nesse caso, os estudos historiográficos devem considerar - como em Bourdieu que a eficácia do direito tem a particularidade de se exercer para além do círculo daqueles que o constituíram. ${ }^{62}$ É preciso que os poderosos negociem a ordem porque, de outra maneira, não poderiam se manter no poder. A lei é elaborada por eles, mas não exclusivamente em favor deles. 0 direito não deve ser pensado como se fosse destinado a um único fim: instrumentar a ordem em favor dos dominantes. Keila Grinberg ${ }^{63}$ também tem contribuido na afirmação dessas ideias. Através da trajetória de alguns escravos, estudadas em ações de liberdade, ela pode comprovar o uso da justiça até mesmo por esses que, formalmente, não teriam direito a demandas na justiça devido à sua incapacidade jurídica. A autora mostra como os escravos puderam acionar a justiça contra seus senhores através das brechas das leis e, como libertos, reivindicavam seus atributos de cidadão. 0 que comprova que "as expectativas sociais em torno da justiça se manifestavam em toda a sociedade e, de modo acentuado, entre aqueles que não detinham poder pessoal ou posição para fazer justiça por seus próprios meios" ${ }^{\prime \prime 4}$. Se os ditos dominados perderam e ganharam causas, os resultados finais de suas lutas na justiça não estavam previamente dados; muitas vezes, eles surpreenderam os poderosos.

Ivan Vellasco ${ }^{65}$, a partir da Comarca do Rio das Mortes, desenvolveu uma relevante análise do funcionamento da justiça criminal. Ao tratar da ordem e seus predicativos, argumentou contra a ideia de que entre os dominados existia uma incapacidade abstrativa de compreensão das regras jurídicas. Ora, ninguém procuraria a justiça se não acreditasse minimamente que sua demanda poderia ser atendida. Nesse sentido, a própria procura pela justiça já era sinal de uma racionalidade que revela noções sobre a ordem coletiva e o papel das instituições em administrá-la. "Conformar-se com o direito para resolver o conflito, é aceitar tacitamente a adoção de um modo de expressão e de discussão que implica a renúncia à violência física (...) e, sobretudo, reconhecer as exigências específicas da construção jurídica"66.

Efetivamente, as fontes aqui analisadas apresentam uma gama variada de clientes acionando a justiça. Ao júri foram apresentados variados tipos de crimes em que personagens diferenciados na hierarquia social revezaram-se na condição de ofendidos e acusados. 0 conselho de São José julgou 24 crimes de morte, quatorze ofensas físicas, um roubo, um crime de abuso de poder e outro de insulto. Essas ações criminais foram desencadeadas por vários motivos: castigo, rixa antiga, desentendimentos, resistência a prisão, vingança e motivação passional, e se efetivaram por diversos meios: espancamento, tortura, tiro, facada, afogamento, enforcamento e paulada. De fato, os resultados dos sentenciamentos não se apre- 
67

COSTA, Emilia Viotti da. Da Monarquia à República: momentos decisivos. São Paulo: Editora UNESP, 2010. p.295.

Processo Criminal do Fórum de Oliveira, caixa 1, documento 22. 1835/1860. Instituição de Guarda: UFSJ/LABDOC.

69

FOUCAULT, Michel. Op. Cit., p.81. sentaram marcadamente favoráveis àqueles a quem poderíamos chamar de dominantes. Até mesmo porque, nos processos analisados, os embates configurados em crime ocorreram, principalmente, entre indivíduos socialmente iguais. Alguns casos, entretanto, chamam a atenção.

Antes de apresentar o único processo analisado que tipifica a antítese senhor/escravo, vale acrescentar mais uma colocação sobre o júri que, de um lado, corresponde à noção aqui levantada de que a instituição formava-se por indivíduos de maior representação social e, de outro, é oposta ao que os dados da pesquisa demonstram sobre a atuação do júri em São José. Para Emília Viotti,

\footnotetext{
0 corpo de jurados era recrutado principalmente entre fazendeiros e proprietários de escravos, pessoas de maior representação social. 0 interesse de grupo raramente permitia que os ideais humanitários, consagrados na lei, prevalecessem. Impediam às vezes a própria ação da justiça. A representação do crime e da culpabilidade era inconscientemente deformada pelos estereótipos vigentes. Via-se o escravo como culposo permanente. 0 senhor, aos olhos do júri, parecia sempre ter razão. Se a legislação era pouco eficaz na defesa do escravo, revelava-se atuante na defesa dos interesses senhoriais. ${ }^{67}$
}

Em 16/01/1835, Manoel Rodrigues Santos matou seu escravo José preto. Consta dos autos que foi um crime brutal motivado pela aplicação de um castigo. 0 corpo de delito apontou ferimentos nas costas, nádegas e pescoço feitas com pau, fogo e corrente. José preto foi achado morto no largo da praça da capela de Santa Ana do Jacaré onde havia sido espancado. As testemunhas relataram que o agressor, enquanto surrava o escravo, dizia que não temia matá-lo, "porque a justiça Ihe dava tempo para vender o que possuía e mudar-se", e dizia, ainda, "que o havia de matar porque se matasse matava o seu dinheiro". 0 crime foi julgado pelo conselho de acusação em 15/01/1836, quando se reputou matéria para acusação do réu, e o promotor público passou mandado para prisão do acusado. Contudo, em 25/04/1860, quando uma última vista foi dada no processo, ainda se pedia o cumprimento do despacho que requereu a prisão do réu. ${ }^{68}$ Ele tinha razão, a justiça Ihe dava tempo para fugir. Essa foi uma tônica recorrente nos processos analisados. Esse senhor se livrou impune, assim igualmente ocorreu em outros 37 casos: os réus julgados desfavoravelmente no júri de acusação não foram presos (e não estavam afiançados), sequer foram julgados pelo júri de sentença. Exclui-se dessa soma um caso em que o júri achou matéria para acusação, mas o queixoso não quis levar adiante o processo. Nesse caso, a inoperância da justiça não esteve diretamente vinculada ao exercício do júri, mas as ações judiciárias posteriores a sua atuação. A partir dessa constatação não vejo em que o conselho de São José possa ter frustrado as expectativas a ele destinadas na melhora da justiça.

Por certo, a impunidade prevaleceu no Termo de São José. Naqueles 37 casos, décadas após o parecer do conselho de acusação, ou os processos haviam sido arquivados ou ainda se aguardava a prisão dos réus para que eles seguissem adiante. Ao que parece, essa realidade ligava-se a outra ordem de problemas que não a questão de deixar impunes os poderosos. Primeiro, porque a impunidade existiu para todos e de maneira alguma ela beneficiou o Estado identificado aos dominantes, visto que "nada torna mais frágil o instrumento das leis que a esperança da impunidade"69. "A justiça foi uma das engrenagens de legitimação do poder imperial (...) o interesse em manter a ordem afirmava-se como precondição para o exercício sistemático do 
VELLASCO, Ivan. Os Predicativos da Ordem..., Op. Cit., p.196.

71

Processo Criminal do Fórum de Oliveira, caixa 1, documento 04. 1830/1860. Instituição de Guarda: UFSJ/LABDOC.

72

Ibidem, documento 17. 1834/1855. Instituição de Guarda: UFSJ/LABDOC.

73

Ibidem, documento 07. 1832/1859. Instituição de Guarda: UFSJ/LABDOC.

74

Ibidem, documento 19. 1835/1860. Instituição de Guarda: UFSJ/LABDOC. poder", por isso, na construção de sua legitimidade aquele Estado precisava que a justiça não se identificasse com uma farsa. ${ }^{70}$ Segundo, porque os réus não se livraram soltos devido a julgamentos arranjados, mas porque a fuga foi uma constante. A impunidade esteve associada à falta de mecanismos de vigilância que pudessem assegurar as determinações judiciais. Os criminosos, conscientes de que a fuga os desoneraria das consequências de seus atos, não temiam cometê-los. Os meios de repressão eram sabidamente frágeis. Manoel Rodrigues, sem qualquer cautela, matou seu escravo em praça pública sem que ninguém interviesse, anunciou a sua fuga e sumiu. Em outro caso ocorrido no arraial do Cláudio, Antônio Caetano invadiu e matou João Pereira Barroso na casa dele e ali foi preso em flagrante, mas no percurso entre a casa e a cadeia do termo se jogou em um rio e dali desapareceu..$^{71}$ Aparentemente, 0 ato da prisão não era uma tarefa fácil e não contava com pessoas preparadas para sua execução. 0 oficial de justiça da paróquia de Oliveira, Quirino José dos Santos, empenhado em prender forros e cativos que jogavam ilicitamente, foi espancado com pau e mordido pelo escravo Elias, que resistiu à prisão e "fugiu partindo em carreira"72. Ainda, um terceiro crime demonstra o grau de destemor à justiça presente em todos os agrupamentos sociais. 0 escravo Miguel matou, em emboscada, Venâncio José da Costa por motivo de uma rixa antiga havida entre os dois. Segundo relato das testemunhas, o réu fugiu gritando que não culpassem pessoa alguma por essa morte que ele havia feito de sua própria vontade. ${ }^{73}$

Apenas três crimes passaram por juízo de acusação e de sentença. Embora uma amostra tão pequena não seja significativa para esclarecimento do modo como o júri sentenciou, ela pode, minimamente, indicar que esse conselho não se comprometeu frente a sua comunidade. No primeiro processo, na paróquia de Oliveira, em 24/05/1835, José Fialho foi ferido com 22 chumbadas por João Luís - os dois se desentenderam, porque o agressor havia "desencaminhado" a mulher do ofendido. 0 júri achou matéria para acusação contra o réu em 14/07/1835. A prisão do acusado somente foi efetivada nove anos depois, em 1844. Permaneceu nessa condição até 1847, quando foi julgado pelo júri de sentença e absolvido. Após tantos anos da ocorrência do crime as testemunhas não compareceram no novo interrogatório - uma inclusive, já havia morrido. Tal fato foi determinante para o livramento de João Luis. ${ }^{74} 0$ segundo processo é bem interessante, trata-se de uma queixa empreendida por Jerônimo Martins contra os Capitães José da Silva Botelho e Custódio José Machado: juiz de paz de Oliveira no ano de 1835. Naquele ano, queixa-se o ofendido de ter sido preso arbitrariamente e conservado na prisão por cinco dias sem direito imediato a fiança. Sua prisão se efetuou porque o capitão Botelho disse que Jerônimo havia jurado falsamente contra ele em processo que 0 mesmo movia contra o capitão Serafim Ribeiro de Castro, protetor do ofendido. Entre o capitão Serafim, o queixoso e os capitães Botelho e Custódio havia inimizade antiga. Configura-se nesse caso, um típico exemplo de abuso de poder, ou antes, de disputa pelo poder, visto que todos já haviam ocupado, naquele distrito, funções de comando. Entre todos os processos, não surpreendentemente, este foi aquele que encontrou na justiça a mais rápida resolução: seus trâmites se desenvolveram de maneira breve e eficaz. Iniciado em 08/04/1836 foi julgado em acusação em 22/07/1836 quando se achou matéria para acusação dos réus; o juízo de sentença condenou o capitão Botelho em 28/07/1836. Ele, porém, impetrou recurso à Relação e foi atendido no mesmo ano. Ficou decidido que um novo pro- 
Ibidem, documento 26. 1836/1839. Instituição de Guarda: UFSJ/LABDOC.

76

Ibidem, documento 38. 1838/1860. Instituição de Guarda: UFSJ/LABDOC.

77

A declaração demonstra que o jurado não concordava com a decisão da maioria e que fora vencido por ela.

78

Astro de Minas, São João Del- Rei, 14 de julho de 1835, n. 1192

79

SILVEIRA, Marco Antônio. O Universo do Indistinto: Estado e Sociedade nas Minas Setecentistas (1735-1808). São Paulo: HUCITEC, 1997, p. 95.

80

ANTUNES, Álvaro de Araujo. Considerações sobre o domínio das letras nas Minas Setecentistas. Lócus, Juiz de Fora, v.6, n. 2, p.16, junho-dezembro, 2000

81

CERTEAU, Michel de. A invenção do cotidiano. Trad. Ephraim Ferreira Alves. Petrópolis: Vozes, 1994. p.264. Apud. ANTUNES, Álvaro de Araujo. Op. Cit., p. 16 cesso fosse aberto e novos jurados julgassem a causa. ${ }^{75} 0$ terceiro processo é relativo a uma briga ocorrida no Arraial de Santo Antônio do Amparo em 02/12/1838. Um grupo de quatro indivíduos, saídos de um bar e estando armados, encontrando seus rivais na rua, espancaram-Ihes. 0 júri achou matéria para acusação dos réus em 15/04/1839; em 24/04/1841 o júri de sentença absolveu um dos acusados, após ser inocentado por seu próprio acusador. Os outros réus não foram sentenciados; o promotor, em 1860, ainda pedia esclarecimento sobre eles. ${ }^{76}$

Os 41 processos desta pesquisa não representam a totalidade dos crimes que realmente ocorreram e que foram julgados pelo conselho sanjoseense (parte da documentação se perdeu em uma enchente ocorrida na cidade de Oliveira). Atesta o fato um artigo, de 1835, publicado no Astro de Minas, sobre o conselho de São José, relativo a um processo não relacionado entre os analisados neste estudo. 0 artigo assevera a perspectiva de Maria Sylvia: seu autor estava convencido da incapacidade mental dos jurados para exercício dos atos judiciários. Ele acreditava ser preciso suprimir alguns círculos de reunião de jurados para concentrá-los em lugares onde se achasse melhor instrução. Fundamentou seu parecer descrevendo um caso havido no júri de São José. Segundo ele, entrou em júri de acusação o feito de um homicídio plenamente provado e os jurados atestaram a materialidade do crime. Contudo, quando foram assinar seus nomes lembrando um de se declarar vencido ${ }^{77}$, todos os que se seguiram a ele também assim o fizeram, de sorte que apareceram dezoito vencidos. "Este fenômeno de dezoito vencer a cinco maravilhou o juiz de direito que os fez recolher novamente para que reformassem a sentença"78. No entanto, a nova sentença absolveu o réu ainda no primeiro júri. 0 redator se revoltou contra o fato, embora declarasse que estava convencido da absolvição do réu no segundo júri, visto que sua defesa estava muito bem montada.

Mas o que prova o fato relatado? Um engano de procedimento testifica a incapacidade intelectual dos jurados? Em vários outros processos pesquisados, alguns jurados se declararam vencidos e não desencadearam ocasião de engano. A mostra de ocupações dos jurados parece ser mais adequada para conformar o perfil intelectual desse grupo. Existia no conselho uma série de pessoas cuja ocupação demandava-Ihes apuro instrucional: eclesiásticos, boticários, solicitador, cobrador, professor, promotor interino. Outro aspecto, embora controverso, pode confirmar o perfil intelectual dos jurados: o índice de alfabetização desse grupo. Os jurados assinaram, todos eles, seus nomes. De acordo com Marco Antônio Silveira a assinatura era sinal de alfabetização uma vez que, recorrentemente, nos processos, o escrivão advertia que os sujeitos deixavam de assinar ou assinavam com cruz "por não saber ler e escrever"79. No entanto, como pondera Álvaro Antunes em alusão a Luiz Villata "ler e escrever eram atividades que podiam estar dissociadas uma da outra"80. Desse modo, a assinatura não implicaria, necessariamente, prova de alfabetização - habilidade identificada ao conhecimento da escrita e da leitura. Decerto, essas capacidades "estiveram por muito tempo separadas no passado, até durante bom trecho do século XIX"81 quando seriam unidas pela escola. Assim, guardados os cuidados por tais considerações, o modo como os nomes eram escritos - se realmente assinados ou desenhados - pode ser um indicador, mais preciso e menos apressado, de que os jurados sabiam ler e escrever, principalmente, se somamos a essa verificação o conhecimento das ocupações a que se dedicavam. A escrita da maioria dos jurados, ao 
CAMPOS, Adriana Pereira, BETZEL, Viviani Dal Piero. Júri no Brasil Império: polêmicas e desafios. In: RIBEIRO, Gladys Sabina (org.). Brasileiros e cidadãos: modernidade política 1822-1930. São Paulo: Alameda, 2008. p.243.

CARVALHO, José Murilo de. Cidadania: tipos e percursos. Estudos Históricos, Rio de Janeiro, n.18, 1996, p.337-359. que parece, era firme e corrente, o que leva a crer que eram alfabetizados. Em pouquíssimos casos as assinaturas têm aspecto de rabiscos cuidadosamente desenhados, o que indica analfabetismo ou dificuldade motora relativa à idade avançada. Relativamente à alfabetização parece haver uma certeza: seus índices mais se elevaram entre a população masculina bran$c a^{82}$, justamente, a identificada ao júri: enquanto, no Termo de São José, os brancos percentualmente representavam $29,5 \%$ da população, no júri eles somavam $87,6 \%$ dos jurados.

Em estudo relativo ao júri capixaba, as autoras, Adriana Campos e Viviani Betzel, também não concordam que esse fosse um grupo formado por ignorantes, antes apontam nomes de pessoas bastante influentes atuando como jurados: "em um Império de iletrados e analfabetos, parece que o júri da província do Espírito Santo não se compunha de homens tão ignorantes como alardeado pelas autoridades. Assim, não procede a crítica de que a simplicidade do júri o debilitava"83. Ao que tudo indica, o júri do Termo de São José constituiu-se por homens intelectualmente habilitados para seu exercício e para orientarem-se segundo as novas normas legais do Estado Brasileiro. Como antes discutido, o júri formava-se, essencialmente, pela nata daquela sociedade. Se caso essas pessoas não estivessem aptas para desempenhar o serviço, quem estaria? Ademais complementando a questão acima, é preciso salientar a perspectiva de José Murilo de Carvalho, que identifica o júri como um exercício de cidadania política mais frequente e intenso do que, por exemplo, o exercício do voto, pois o conselho de jurados atuava mais vezes e se delongava mais na exposição às leis. Donde o autor supõe que o contato com o Estado, no exercício do júri, era mais profundo, e a socialização política dele resultante era mais eficaz que 0 ato de votar ${ }^{84}$. Assim, o próprio exercício do júri adestrava seus participantes no entendimento do modo como a justiça deveria se operacionalizar.

Interessante é que a alfabetização não era um privilégio restrito aos juízes. Relativamente às testemunhas que relataram os fatos nos autos, e que dividiram com os jurados a rotina das sessões de julgamento, verifica-se um indice de alfabetização considerável. É o que pode ser verificado na tabela 7.

Tabela 7. Índice de alfabetização das testemunhas dos processos criminais ajuizados pelo conselho de jurados do Termo de São José (1832-1841)

\begin{tabular}{|c|c|c|c|c|c|c|}
\hline Cor & Assina & $\%$ & Assina Cruz & $\%$ & Não consta & Total \\
\hline Pardo & 89 & 42,3 & 57 & 44,5 & - & \\
\hline Branco & 109 & 51,9 & 48 & 37,5 & - & \\
\hline Crioulo & 8 & 3,8 & 13 & 10,2 & - & \\
\hline Cabra & 3 & 1,5 & 3 & 2,3 & - & \\
\hline Preto & 1 & 0,5 & 7 & 5,5 & - & \\
\hline Total & 210 & & 128 & & 16 & 354 \\
\hline$\%$ & 59,3 & & 36,2 & & 4,5 & 100 \\
\hline
\end{tabular}

Autoria: Viviane P. C. Silva Ameno (software SPSS - Statistical Package for the Social Sciences) Fonte: Processos Criminais Fórum de Oliveira (documentos 1 a 43)

Se contemplarmos a alfabetização como condição intelectual favorecedora da incorporação de orientações legais, é possivel incluir também as testemunhas dos processos em São José entre os clientes da nova 
85

De acordo com Álvaro Antunes embora indícios sugiram que havia "um domínio das letras superior entre homens do que entre as mulheres, bem como uma difusão desigual do conhecimento da escrita entre segmentos sociais," não havia, entretanto, "um exclusivismo por parte de uma elite branca". É com essa perspectiva que a tabela 8 deve ser tomada, embora ela levante todos os problemas acima descritos em relação a "assinaturas" e "alfabetização".ANTUNES, Alvaro de Araujo. Op. Cit., p.19.

86

Anaes do Parlamento Brasileiro, Assembleia Legislativa, sessão de 11 de maio de 1826. Fala do deputado Clemente Pereira, p. 48. Disponivel em: <www2.camara.gov.br>. Acesso: 16/03/2012.

87

Fala dirigida à Assembléia Legislativa Provincial de Minas Gerais na sessão ordinária, do ano de 1837, pelo presidente da província Antonio Costa Pinto. Ouro Preto, Typografia do Universal, 1837. Disponivel em: www.crl.edu . Acesso em: 28/04/2011.

88

Ibidem.

89

Segundo o artigo 314 do Código do Processo não se poderia principiar sessão sem que estivessem presentes 48 jurados, mas na prática a realidade se efetivou de outra maneira. Há casos em que as sessões, no Termo de São José, se realizaram com 42 jurados.

90

Anaes do Parlamento Brasileiro, Assembleia Legislativa, sessão de 15 de julho de 1826. p. 75. Disponivel em: <www2.camara.gov.br $>$.Acesso em: $16 / 03 / 2012$.

91

Fala dirigida à Assembléia Legislativa Provincial de Minas Gerais na sessão ordinária, do ano de 1837, pelo presidente da província Antonio Costa Pinto. Ouro Preto, Typografia do Universal, 1837. Disponivel em: www.crl.edu . Acesso em: 28/04/2011. justiça, ou seja, entre aqueles que dispunham de recursos intelectuais para compreendê-la e utilizá-la. ${ }^{85}$ Obviamente, 0 adestramento da sociedade às novas perspectivas legais não se daria de maneira imediata; seria necessário um ostensivo trabalho de publicização, afinal, "é um princípio certo em direito público que as leis não podem obrigar, sem serem conhecidas por todos" ${ }^{\prime 66}$. Depois, essa justiça deveria apresentar-se à sua clientela como locus seguro de satisfação de seus interesses, onde a previsibilidade da lei e sua efetivação garantissem maior ganho ao impetrante do que a resolução de sua causa por seus próprios meios. Daí que a modificação da lei não bastava para estabelecer uma nova justiça, sua reestruturação dependia de um aspecto fundamental que repercutia diretamente no sucesso do empreendimento, dado que sua falta atravancava os serviços do judiciário: a estrutura operativa ou os meios que viabilizariam a execução das prescrições dos códigos criminal e do processo, entre eles, boas estradas, boas cadeias e um bom policiamento.

\section{Óbices aos bons serviços judiciários}

Sob todos os aspectos, a estrutura disponivel não concorria para o bom andamento da justiça. Em 1837, alertava o presidente da província mineira, Antônio Costa Pinto, sobre a necessidade da empresa de obras públicas. Dizia ele que era indispensável o feito de obras municipais e reclamava atenção especial às estradas e cadeias. Em suas palavras, nada se estava empreendendo para melhora das estradas "não podendo ser mais perigoso, e lamentável o estado de ruína a qual elas tem chegado"87. Refletia acertadamente que sem as estradas

Em um pais como o nosso onde as instituições e as leis ordenam o comparecimento dos cidadãos para preencherem tão multiplicados e variados deveres, o serviço público não pode deixar de padecer. É pela falta de meios de comunicação que não tem sido possivel corresponderem se prontamente as autoridades de uma mesma comarca, e até de um mesmo termo, com manifesto prejuizo público e particular. Urge, pois necessidade de remédio. ${ }^{88}$

Essa realidade no serviço do júri refletia-se na demora da chegada dos jurados as sessões. Às vezes eram necessários três dias de espera até que se completasse o número legal de jurados para que a sessão se iniciasse. ${ }^{89}$ Pelo mapa 1 é possivel presumir as distâncias percorridas pelos jurados e testemunhas para se apresentarem nas sessões que eram realizadas na Vila de São José. Na identificação feita, apenas três localidades não contaram com representantes no conselho sanjoseense: Santana do Jacaré, Carmo da Mata e Cana Verde. Os óbices impostos pelas más condições das vias não se sucediam exclusivamente em Minas. Em 1826 a comissão de justiça civil e criminal expôs o pedido de um juiz de fora de Taubaté rogando providência sobre as estradas que dificultavam suas atividades "em razão das distâncias e impraticabilidade dos caminhos" ${ }^{\prime \prime}$.

A questão prisional igualmente era um problema em todo o território brasileiro. As prisões, além de mal-seguras, eram insalubres e somavam número insuficiente. 0 novo sistema de penas era baseado na restrição da liberdade e carecia, portanto, para cumprimento de seu objetivo, de prisões adequadas. Do contrário toda a justiça seria débil, pois "sem as cadeias, quando não seja impossivel, é por certo muito difícil proceder-se com regularidade na administração da justiça" ${ }^{91}$. 0 resultado de um lado era a impunidade que desacreditava a justiça, de outro, o péssimo trato propor- 
92

Anaes do Parlamento Brasileiro, Assembleia Legislativa, sessão de 29 de agosto de 1826. Fala do deputado Costa Aguiar. p.75. Disponivel em: <www2.camara.gov.br>. Acesso em: 16/03/2012.

93

Fala dirigida à Assembléia Legislativa Provincial de Minas Gerais na sessão ordinária, do ano de 1840, pelo presidente da província Bernardo Jacintho da Veiga. Ouro Preto, Typografia do Correio de Minas, 1840. Disponivel em: www.crl.edu . Acesso em: 28/04/2011.

94

BRETAS, Marcos Luiz. A Polícia Carioca no Império. Revista de Estudos Históricos, Rio de Janeiro, vol.12, n.22, 1998, p.225.

95

Ibidem, p.230. cionado ao condenado quando preso. A solução do problema parecia ser para os legisladores um feito pouco provável

\begin{abstract}
Não se podendo duvidar do atraso em que a este respeito estamos por não as ter ainda no Império, e nem permitem as circunstancias que possamos ter cadeias e prisões limpas, arejadas e acomodadas as diversas qualidades dos delitos e dos delinqüentes, pois que a maior parte das prisões, ou talvez todas, servem mais de hórridas e medonhas sepulturas de vivos, do que de correção e de castigo dos crimes. ${ }^{92}$
\end{abstract}

A situação na Comarca do Rio das Mortes não era diferente. Em fala dirigida a assembleia provincial, o presidente, Bernardo Jacintho da Veiga, no ano de 1840, apresentou a realidade de Minas e, ao referir-se a Comarca, disse:

$\mathrm{Na}$ Comarca do Rio das Mortes existem três cadeias, à exceção da que de novo se está construindo na cidade de São João del-Rei , de cujo estado já dei notícia: a que ali serve atualmente é inferior (diz o juiz de direito) a qualquer idéia desvantajosa que dela se possa formar; a de Lavras pequena e mal segura; e a da Vila de São José atualmente em construção tem tido algum progresso, servindo ainda de prisão a mesma casa em que a câmara celebra as suas sessões, e que não oferece os cômodos e segurança precisa para retenção dos criminosos. ${ }^{93}$

Completando o quadro, a polícia, como instituição garantidora do cumprimento da lei, estava apenas no início de sua sistematização. Esse aparelho coativo, que poderia assegurar a eficácia do novo ordenamento pela prevenção dos crimes, pela imposição da obediência às leis, pela vigília dos perturbadores da ordem e pela prisão dos contraventores não era uma realidade a serviço do Estado e da sociedade. 0 número de policiais não era o bastante: "por uma boa parte do Império o número de policiais era pouco superior à metade do previsto"94. Além do mais, o pouco efetivo não se constituía por pessoal de boa qualidade, como adverte Marcos Bretas: "mesmo o quadro de oficiais promovidos das fileiras indica as deficiências do pessoal engajado (...) estamos muito distantes da elite de letrados que se dedicava a construir o sistema legal que esses policiais eram encarregados de aplicar no dia-a-dia"95. Uma vez que as considerações do autor se referem à corte, tanto mais calamitosa deveria ser a situação nas outras regiões do pais. A figura do policial não aparece nos processos criminais aqui analisados. Na verdade, no código do processo de 1832 essa função especifica não existia, ela esteve atribuída aos juízes de paz, aos oficiais de justiça e aos inspetores de quarteirão. Cada distrito dispunha de um juiz de paz, quantos oficiais de justiça se julgassem necessários e tantos inspetores quantos fossem os quarteirões. A atuação dos juizes e oficiais de justiça é evidente nos autos. 0 oficial de justiça mencionado acima, Quirino José dos Santos, era um indivíduo pardo, lavrador, sem escravos. Um outro oficial, Joaquim José de Santana, não indicado entre os jurados devido a homonímia, também era pardo, ocupava-se com a carpintaria. Esses homens dividiam-se entre suas tarefas ocupacionais - em nada identificadas com o serviço da justiça - e as tarefas de agentes do judiciário. Mas quanto do tempo deles era dedicado a cada um destes empreendimentos, visto que um referia-se a manutenção de suas vidas e de suas famílias e outro implicava o bem-comum? Os inspetores de quarteirão, justamente os que atingiam maior número e que, por suposto, participavam de perto do cotidiano das comunidades, no Termo de São José, não são citados nos processos. É provável que não executassem suas atividades com diligência, haja vista 
BUENO, José Antônio Pimenta. Apontamentos sobre o Processo Criminal Brasileiro. São Paulo: Editora Revista dos Tribunais, 1959. p.5.

97

MATOS, Raimundo José da Cunha. Corografia histórica da Província de Minas gerais (1837). Vol.1. Belo Horizonte: Editora Itatiaia, 1981. p.114.

98

ACANDA, Jorge Luis. Op. Cit., p.82.

99

CARDOSO, Ciro Flamarion S. Agricultura, escravidão e capitalismo. Petrópolis: Vozes, 1979. p.73. as muitas fugas não evitadas por esses agentes que tinham autoridade legal para prender criminosos em flagrante, os pronunciados e condenados. Talvez sua aproximação com os membros das comunidades infligisse nesses homens temores ou piedade. Seria preciso investigar melhor esses sujeitos - inspetores e oficiais - que preenchiam, a essa época, função importante e que influenciaram, certamente, no bom andamento da justiça. Não bastava ao direito penal estabelecer seus preceitos com clareza, uma vez que as leis não preencheriam seu fim senão por sua aplicação e, para isso, se necessitava de instrumentos que lhe dessem realidade prática ${ }^{96}$; assim, eram diversos os ajustes reclamados para o bom êxito da nova ordem.

\section{Considerações finais}

Finalmente, volto às indagações realizadas no início do texto. A resposta a primeira e segunda perguntas é afirmativa: o conselho do Termo de São José compunha-se de sujeitos independentes (proprietários) e de boa formação intelectual. A terceira e quarta perguntas apresentam respostas que se implicam. A inserção do sistema de jurados no cenário judicial promoveu a ampliação do número de envolvidos na rotina dos tribunais e, de certa forma, aproximou a justiça da população, uma vez que o conselho de jurados se formava a partir da convocação de eleitores na menor unidade administrativa da justiça: o distrito de paz. A multiplicidade de novos sujeitos atuando na justiça pode ser presumida a partir da contagem dos jurados em cada termo, que, no mínimo, computava o número de sessenta homens. A Comarca do Rio das Mortes, sozinha, compreendia sete termos ${ }^{97}$; daí pode-se imaginar a soma alcançada por todo o Brasil. Todavia, a amplificação de personagens na justiça dada pelo júri foi seletiva e respondeu à racionalidade da política que o promoveu: no liberalismo, pensar a política, (...) pressupõe pensar a propriedade; pensar a política é pensar o homem enquanto proprietário"98. A qualificação exigida para participação no júri era de caráter censitário e, portanto, de natureza limitante. No Termo de São José, o conselho de jurados esteve caracterizado, em sua maioria, pela padronização que regia a cidadania da época: seu exercício foi desempenhado pelos varões brancos e proprietários. Embora esse padrão não garantisse a equidade jurídica entre acusados e sentenciadores aquele júri não comprometeu ou denegriu a imagem da instituição por meio de seus sentenciamentos, haja vista os desfechos dos processos aqui analisados. Assim, ao contrário do que afirmam alguns estudiosos - em perspectiva mais geral sobre o júri no Brasil - o conselho de jurados do Termo de São José não apresentou um alto índice de absolvição entre os acusados julgados, nem mostrou formar-se por um grupo inclinado ao suborno e a pressões de potentados locais. Por certo, toda delimitação territorial é uma abstração e, portanto, uma simplificação de uma realidade mais comple$\mathrm{xa}$, segundo aponta Ciro Flamarion ${ }^{99}$. Tendo em mente esse apontamento, guardo a esperança de que a investigação do conselho de jurados do Termo de São José - um caso entre tantos no Brasil - contribua para afastar a instituição de possiveis generalizações a seu respeito. 